\title{
Classificação e perseguição: os agentes da Inquisição, os negros, pardos e mulatos em uma sociedade escravista. (Alagoas Colonial, 1674-1820).
}

\author{
Alex Rolim Machado ${ }^{1}$
}

Resumo: Apesar de não ter sido instaurado um Tribunal da Inquisição na América portuguesa, é enganoso pensar que suas ações não tenham chegado aos Trópicos. Inicialmente foi pensado para perseguir crimes “europeus”, sendo o principal o judaísmo. Nos territórios americanos, os Agentes do Santo Ofício se reinventaram a todo momento com o tráfico do negro africano, a conquista dos ameríndios e a miscigenação por conta de seus fortes traços culturais e modos de vida. Aprenderam ali a classificar e a perseguir práticas das etnias africanas e americanas. Do mesmo modo, os escravos, forros e livres igualmente se propuseram a usar a Inquisição como ferramenta de resistência, travando em alguns momentos sua suposta maquinação efetiva e voltando-a contra os senhores brancos.

Palavras-chave: Inquisição, Alagoas Colonial, Negro Africano.

\begin{abstract}
Despite not having been instituted a Court of Inquisition in Portuguese America, it is misleading to think that their actions have not reached the Tropics. In the Portuguese America, the agents of the Inquisition reinvented themselves in every moment, with the African slave trade, the conquest of Native Americans, cultural miscegenation and lifestyles. The agents learned there rating and pursue practices from African and American ethnic groups. In the same way, the slaves, and the free, also used the Inquisition as a tool of resistance, putting latches in some moments and turning against the white masters.
\end{abstract}

Keywords: Inquisition, Colonial Alagoas, Black African.

Em 1984, ao escrever um texto acerca de uma teoria para a História Institucional do Antigo Regime, António Manuel Hespanha já tecia comentários críticos sobre como a Inquisição era vista em artigos e livros acadêmicos portugueses: um conjunto de histórias pitorescas de valor históricocrítico baixo, "que muitas vezes preferem os aspectos patéticos e polémicos aos aspectos políticoinstitucionais"”. Dez anos adiante, Francisco Bethencourt lançou sua obra História das Inquisições; um estudo político-institucional comparativo entre as três Inquisições da época

1 Pesquisador do Grupo de Estudos da América Colonial da Universidade Federal de Alagoas. E-mail: arolimm@hotmail.com.

2 HESPANHA, António Manuel. "Para uma teoria da história institucional do Antigo Regime”. In: HESPANHA, António Manuel (org.). Poder e Instituições na Europa de Antigo Regime. Lisboa: Fundação Calouste Gulbenkian, 1984, p. 11. 
moderna: portuguesa, espanhola e italiana ${ }^{3}$, pretendendo suprir essa lacuna da historiografia sobre o estudo do Tribunal, elucidando muitos aspectos que eram conhecidos de leve ou escritos de forma rasteira sobre o funcionamento da instituição.

O presente artigo não pretende estudar apenas os aspectos da Inquisição como Tribunal que julga e persegue, mas também daqueles que foram classificados e perseguidos pelos agentes do Santo Ofício. Nesse caso, enquanto A. Hespanha e F. Bethencourt se preocupavam com os aspectos institucionais e políticos, Laura de Mello e Souza em 1986 lançava sua obra pioneira (e até hoje referência) sobre a religião popular na América portuguesa, sendo uma das primeiras a esmiuçar os aspectos ideológicos da sociedade portuguesa e da Inquisição nos quesitos dos conhecimentos e classificações das práticas religiosas dos africanos traficados e dos ameríndios que cá já estavam antes da chegada dos conquistadores portugueses ${ }^{4}$. Depois de sua iniciativa, outros temas como o casamento, a sexualidade, os crimes eclesiásticos e a formação das redes de agentes do Santo Ofício foram aparecendo em maior número e com um rigor teórico e metodológico apurado ${ }^{5}$. Contudo, é importante frisar que o tema da Inquisição já era conhecido em espaços brasileiros a partir das iniciativas de Anita Novinsky e de Sônia Siqueira ${ }^{6}$.

Portanto, dividir-se-á o texto aqui proposto em dois pontos sociais. Primeiramente, a partir de alguns estudos de caso, avaliar-se-á como os agentes da Inquisição foram criados nos espaços locais. E a partir de suas práxis de perseguição classificavam os africanos e seus descendentes como "má-vindos" na sociedade tanto pelos ideais antigos (a pureza de sangue portuguesa) como costumeiros (a miscigenação nos Trópicos) ${ }^{7}$. Ali suas presenças foram demasiadas elásticas nos

3 BETHENCOURT, Francisco. História das Inquisições: Portugal, Espanha, Itália. Lisboa: Círculo de leitores, 1994.

4 SOUZA, Laura de Mello e. O diabo e a terra de Santa Cruz: feitiçaria e religiosidade popular no Brasil colonial. $-2^{\mathrm{a}}$ ed. São Paulo: Companhia das Letras, 2009.

5 VAINFAS, Ronaldo. Trópico dos pecados: moral, Sexualidade e inquisição no Brasil. - Rio de Janeiro: civilização Brasileira, 2010. MOTT, Luiz. Bahia: Inquisição \& Sociedade. - Salvador: EDUFBA, 2010. VAINFAS, Ronaldo. FEITLER, Bruno. LIMA, Lana Lage da Gama. (org.). A Inquisição em xeque: temas, controvérsias, estudos de caso. - Rio de Janeiro: EdUERJ, 2006. CALAINHO, Daniela Buono. Agentes da fé: familiares da Inquisição portuguesa no Brasil colonial. Bauru: EDUSC, 2006.

6 NOVINSKY, Anita. Cristãos-novos na Bahia. São Paulo: Perspectiva, 1972. SIQUEIRA, Sônia. A Inquisição portuguesa e a sociedade colonial. São Paulo: Ática, 1978.

7 Ronaldo Vainfas vai delimitar essa diferença entre "Pureza de Sangue" e "Preconceito de cor", que apesar de terem 
quadros sociais, como indivíduos renegados em alguns momentos, ou até mesmo bem-vindos em outros, dependendo do grau de interesse do branco conquistador ${ }^{8}$. Outros casos permitem avaliar como eram dadas as perseguições quando algum tipo de "crime" de alçada inquisitorial era identificado e seu proponente denunciado e/ou preso. A partir das leituras dos discursos e sua análise temática, ver-se-á as denominações e caracterizações dadas quando um negro, pardo ou mulato era encarado como "inimigo da fé católica".

A segunda perspectiva aqui é de retomar um debate "materialista-social" em torno da sociabilidade dos negros e seus descendentes dentro da comunidade conquistadora branca ${ }^{9}$. Ensaios atuais (baseados em larga leitura bibliográfica e pesquisa empírica) se propõem a demonstrar a importância dos múltiplos estudos das etnias africanas e ameríndias nos espaços das conquistas do Império português ${ }^{10}$. Tomando aqui uma posição de olhar analítico entende-se que indicar as

se tornado quase sinônimos no Brasil, por conta da estrutura da escravidão, são diferentes em seus estatutos jurídicos e costumeiros. Cf. VAINFAS, Ronaldo. "Moralidades brasílicas: deleites sexuais e linguagem erótica na sociedade escravista”. In: MELLO E SOUZA, Laura de (org.). História da vida privada no brasil: Cotidiano e vida privada na América portuguesa, vol. I. NOVAIS, Fernando. (dir.). - São Paulo: Companhia das Letras, 1997, pp. 238-239.

8 FRAGOSO, João. “Capitão Manuel Pimenta Sampaio, senhor do engenho do Rio Grande, neto de conquistadores e compadre de João Soares, pardo: notas sobre uma hierarquia social costumeira (Rio de Janeiro, 1700-1760)". In: FRAGOSO, João. Gouvêa, Maria de Fátima (orgs.). Na trama das redes: política e negócios no império português, séculos XVI - XVIII. - Rio de Janeiro: Civilização Brasileira, 2010. Cf. VAINFAS, Ronaldo. “A tessitura dos sincretismos: mediadores e mesclas culturais". In: FRAGOSO, João \& GOUVÊA, Maria de Fátima. (orgs.). O Brasil colonial: volume 1 (ca. 1443- ca.1580). - Rio de Janeiro: Civilização Brasileira, 2014. Só para ficar em dois exemplos: o primeiro no campo das relações de poder, e o segundo no quesito dos sincretismos religiosos.

9 Vários estudos já tratam de tentar identificar a pluralidade étnica dos negros africanos dentro dos espaços da América portuguesa. Nesse artigo, usar-se-á a denominação dada pela documentação do Santo Ofício em relação aos negros e os pardos, visto que suas etnias não foram explicitadas pela documentação redigida (negro Angola, Guiné, Costa, entre outras denominações). Em relação aos pardos, interessante conferir o vocábulo dado por BLUTEAU, Raphael. Vocabulario portuguez \& latino. Áulico, anatômico, architectonico... Coimbra: Collegio das Artes da Companhia de Jesus, 1712-1728, Acessado em www.brasiliana.usp.br/dicionario/edicao/1 em 16/01/2014 às 17:58: "PARDO: Cor entre branco, \& preto, própria do pardal, dõde parece lhe veio o nome. (...) Homem pardo. Vid. Mulato". (Vocabulario Portuguez \& Latino - volume 6, p. 265). "MULATA \& Mulato: Filha, \& filho de branca, \& negra, ou de negro, \& de mulher branca. Este nome Mulato vem do Mû, ou mulo, animal gerado de dous outros de differente espécie”. (Vocabulario Portuguez \& Latino - volume, 5 p. 628).

10 LARA, Silvia Hunold. "Conectando historiografias: a escravidão africana e o Antigo Regime na América 
perseguições contra religiões e práticas africanas é essencial. Mas perderia força de explicação social quando se conclui de modo pouco crítico e se incorpora, sem citar, um "olhar Freyriano". Nele, mesmo com a perseguição contra africanos, ameríndios e seus descendentes, cria-se um universo magnífico e colorido de religiões e práticas sincréticas, fazendo das conclusões históricas espaços de reflexão e crítica racionalista voltada para compreender uma futura identidade nacional, mas não de luta ou de justiça social. Ou seja, mesmo não se acreditando mais no mito da democracia racial (G. Freyre), a "harmonização" das três etnias (e seus grupos étnicos) minimizaria esse processo longo e conflituoso.

O conjunto documental para este estudo foi variado. Devido à falta de pesquisas mais sistemáticas e de um balancete empírico mais apurado para os espaços "alagoanos", priorizou-se aqui casos qualitativos de diferentes naturezas ${ }^{11}$. Teve-se como linha mestra a classificação e perseguição de negros, pardos e mulatos. Sendo ainda estudo inédito para o território sul de Pernambuco: a Inquisição na Comarca das Alagoas ${ }^{12}$. Apesar de poucos, sua pluralidade foi o que garantiu a esse texto as hipóteses que aqui se pretendem demonstrar.

O recorte espacial será o que se compactua aqui chamar de "Alagoas Colonial”, proposição primeiro pensada por Antonio Filipe Pereira Caetano, ao atribuir no espaço sul de Pernambuco algumas ideias iniciais sobre a relativa autonomia política, tanto da administração, quanto de alguns

portuguesa". In: BICALHO, Maria Fernanda Baptista. FERLINI, Vera Lúcia Amaral. (orgs.). Modos de governar:idéias e práticas políticas no império português - séculos XVI-XIX. - São Paulo: Alameda, 2005, pp. 2138. MATTOS, Hebe. “Colonização e escravidão no Brasil - Memória e historiografia”. In: FRAGOSO. GOUVÊA. Op. Cit., 2014.

11 Por conta de espaço, retirou-se aqui da análise casos, por exemplo, de pardos (as) bígamos (as).

12 Luiz Mott, no seu artigo citado (Bígamos de Alagoas nas garras da Inquisição, op. Cit., 2012), deixa transparecer certo entristecimento com o fato de, desde 1992 até 2012, nenhum historiador alagoano ter se aprofundado nos estudos inquisitoriais abertos por ele. Anita Novinsky, em uma entrevista rápida para o dossiê de Inquisição da Revista de História da Biblioteca Nacional, em outubro de 2011, tratou o território alagoano como "virgem" pela falta de pesquisas e interessados nos estudos da Inquisição e do Santo Ofício. Nas palavras da historiadora: "Tudo ainda está por ser estudado na história da Inquisição no Brasil, que atuou do Amazonas ao Rio Grande do Sul. Há estados ainda não pesquisados, completamente virgens, como Alagoas”. Cf. NOVINSKY, Anita. Entrevista por Rodrigo Elias. Revista de História da Biblioteca Nacional, Ano 7, $\mathrm{n}^{\mathrm{o}}$ 73, Outubro de 2011, p. 32. Sobre o primeiro estudo de Luiz Mott, cf. MOTT, Luiz. “A inquisição em Alagoas”. Debates de História Regional (Revista do departamento de história da UFAL), nº 1, Maceió, 1992. 
costumes locais, indicando não uma independência, mas dinâmicas próprias ${ }^{13}$. Hipóteses sobre como usar esse conceito para o estudo da Inquisição se encontram no final do texto. O leitor primeiro terá que acompanhar o passo-a-passo para compreender (ou até discordar) do porquê de “Alagoas Colonial” ser uma chave-teórica cabível para tal tipo de estudo e jurisdição.

O recorte temporal obedecerá as ideias dos parágrafos anteriores. Como aqui se pretende estudar a relação da Inquisição (e de seus agentes "alagoanos") com os "crimes" acontecidos nos espaços das vilas do sul de Pernambuco, pretende-se ter como ponto inicial a formação dos primeiros quadros dos agentes inquisitoriais em "Alagoas". A saber, o pedido de habilitação de Severino Correia da Paz, em 1674, dando o pontapé inicial para outras habilitações futuras (inclusive na própria família), e a última habilitação, sendo ela de 1820. Todos os processos e denúncias aqui analisados pertencem em exclusivo ao século XVIII. No entanto, como o texto se propõe a estudar dialeticamente a relação entre agentes repressores e agentes perseguidos toma-se como ponto inicial o primeiro Familiar do Santo Ofício "alagoano" e, o final, o último Familiar. Mesmo que no ano seguinte (1821) tenha sido decretado o fim da Inquisição portuguesa, cessando a perseguição inquisitorial. Ações repressivas de outras maneiras contra os negros, ameríndios e seus descendentes, fossem escravos ou não, foram continuamente reelaboradas no período imperial e republicano.

\section{Classificação.}

Para o Regimento do Santo Ofício era proibida, em seus quadros internos a admissão de agentes que tivessem sangue de "raça de infecta nação", assim como culpados e sentenciados pela própria Inquisição e Justiça Secular; pais de filhos ilegítimos também não deveriam ser aceitos como oficiais do tribunal ${ }^{14}$. O ideal da pureza de sangue não foi algo que nasceu com a conquista da

13 CAETANO, Antonio Filipe Pereira. “'Existe uma Alagoas Colonial?' Notas preliminares sobre os conceitos de uma Conquista Ultramarina." In: Revista Crítica Histórica, Ano I, no 1, Junho/2010. Acessado em http://www.revista.ufal.br/criticahistorica/ (dia 16/05/2012). Arthur Curvelo defendeu atualmente sua dissertação de Mestrado, onde conseguiu demonstrar que pelo menos a Câmara da Vila das Alagoas, no contexto recortado, atuou em diversos momentos em assuntos à parte do Governo de Pernambuco. Cf. CURVELO, Arthur. O Senado da Câmara de Alagoas do Sul: Governança e poder local no sul de Pernambuco (1654-1732). - Universidade Federal de Pernambuco, Centro de Filosofia e Ciências Humanas, programa de Pós-Graduação em História (dissertação de Mestrado), Recife, 2014.

14 Regimento de 1640. Livro I, Título I, §2. Apud: RODRIGUES, Aldair. Sociedade e Inquisição em Minas Colonial: Os Familiares do Santo Ofício (1711-1808). Dissertação (mestrado). FFLCH-USP, departamento de 
África e muito menos da América, mas já advinha de Portugal no período da reconquista quando mouros, judeus e outras "raças" não eram admitidas nos quadros burocráticos, políticos e nobres das localidades. Apesar da relativa "admissão" dos mesmos nos quadros sociais locais ${ }^{15}$. Com as conquistas da África, suas feitorias, a invasão na América, ocupação, miscigenação e outras trocas e intercâmbios culturais, os portugueses trataram por reafirmar de maneiras modeladas sua condição de branco "puro", europeu e diferente daquelas "raças de infecta nação". Pretendiam, mesmo fora do reino, alçar ainda um estatuto de fidalgo, nem que fosse reinventando-se e criando novas tradições e costumes; aliados, na maioria dos casos, a seus próprios interesses (de conquistador, e de representantes da Monarquia portuguesa católica e mercantilista) ${ }^{16}$. Para não fugir da proposta do artigo, focar-se-á no tópico da "pureza de sangue" sempre que possível, uma vez que o foco apresentado dá-se sobre a relação intrínseca entre as ações da Inquisição e as ações de pessoas negras, pardas e mulatas ${ }^{17}$.

\subsection{Formação da polícia ${ }^{18}$ do Santo Ofício: a negação das raças.}

História, São Paulo, 2007, p. 92-93.

15 TORRES, José Veiga. "Da Repressão Religiosa para a Promoção Social. A Inquisição como instância legitimadora da promoção social da burguesia mercantil". Revista Crítica de Ciências Sociais, no 40, Outubro 1994. BOXER, Charles. O império marítimo Português. 1415-1825. Tradução de Anna Olga de Barros Barreto. São Paulo: Companhia das Letras, 2002, pp. 273-275.

16 "Ser familiar do Santo Ofício significava $<<$ enobrecer-se $>>$, o que implicava ter $<<$ pureza de sangue $>>$, requisito básico para a habilitação àquela honraria. Significava, por vezes, utilizar-se dessa qualificação para, além das benesses, prerrogativas, privilégios e prestígio social que lhes eram adstritos, tirar proveito em negócios. $(. .)<.<$ mas os familiares eram mais do que meros espiões. Espécie de 'intermediários' entre o Tribunal e a população, exerciam múltiplas funções. Recebiam denúncias e tinham obrigações de informar a Mesa inquisitorial das causas 'pertencentes à Santa Fé'. Zelavam pelo cumprimento das penas dos réus e a sua aparição pública era notória, acompanhando os penitenciados nos autos-de-fé e dando um peso singular a este rito $>>$. (...) <<em regra, eram os executores das prisões e responsáveis pelos sequestros de bens nos casos cabíveis $>>$ ". BOSCHI, Caio. "Estruturas eclesiásticas e Inquisição". In: BETHENCOURT, Francisco. CHAUDHURI, Kirti. (dir.) História da Expansão Portuguesa vol. II: Do Índico ao Atlântico (1570-1697). Lisboa: círculo dos leitores, 1998, p. 452

17 Sobre a questão da pureza de sangue como promoção social, cf. VEIGA TORRES. Op. Cit., p. 119. Partindo para outras posições dos poderes dos agentes, interessante e importante conferir RODRIGUES. Op. Cit., 2007, pp. 7374. Cf. CALAINHO, Daniela Buono. "Pelo reto ministério do Santo Ofício: falsos agentes inquisitoriais no Brasil colonial”. In: VAINFAS. FEITLER. LIMA. (orgs.) Op. Cit., 2006, pp. 92-95.

18 Utilizar-se-á o conceito de António Manuel Hespanha para "polícia” no século XVII, de acordo com as doutrinas 
Julga-se aqui que a relação familiar era um dos tópicos mais importantes para alguém que estava se habilitando a se tornar agente da Inquisição em solos americanos. Seria consenso na historiografia atual a conclusão que o ponto mais visado pela Inquisição, ao admitir uma pessoa em seus quadros institucionais, era descobrir se o pretendente a Familiar do Santo Ofício era cristãonovo ou descendente de alguma "raça impura"19. A partir disso, a relação matrimonial é um assunto que deve ser tratado de maneira delicada, visto seu peso dentro dessas posições que a Inquisição fazia os súditos tomarem, principalmente no que tangiam a afirmação de suas condições, assim como o desejo de manterem tais "limpezas" ao decorrer das gerações.

Ao contrário da descendência (cristão novo, mouro, africana ou ameríndia), o casamento não era obrigatório ao agente do Santo Ofício (nesse caso, os Familiares). Porém, uma vez casado, toda a árvore genealógica da esposa deveria ser pesquisada pelo Comissário da Inquisição e, qualquer desvio dos pontos que eram aplicados ao marido, visto pela instituição, poderia ser fator agravante para o pretendente a agente não ser agraciado com o cargo. Além da descendência, uma vez dito casados, a Igreja obrigaria que tal união tivesse seguido os ritos Tridentinos, que já eram postos em prática em Portugal e foram levados para o além-mar na época das conquistas e colonizações dos $\operatorname{espaços}^{20}$. Deste modo, casar-se não era apenas contrair matrimônio com uma cristã-velha, branca e "pura", mas garantir que a união tivesse obedecido a um rol quilométrico de regras e normas ditadas pela Igreja Católica.

Ronaldo Vainfas, em sua obra Trópico dos Pecados, apesar de focar no estudo da sexualidade, da moral "luso-brasileira" e da perseguição da Inquisição (e sociedade), em relação a algumas práticas condenadas pela Igreja Católica, traz sobre o debate do casamento na colônia pontos de avaliações muito importantes. Para este trabalho, pode-se avaliar o casamento sob dois prismas: 1) perpetuação do ideal de sangue branco europeu e cristão velho, evitando a miscigenação

jurídicas de administração baseadas especialmente em conceitos Aristotélicos: “(...) i,e., a actividade do poder tendente a organizar as actividades económicas e sociais". Cf. HESPANHA, António Manuel. "Para uma teoria da história institucional do Antigo Regime". HESPANHA, António Manuel. Poder e instituições na Europa do antigo regime. Lisboa: Fundação Calouste Gulbenkian, 1984, p. 15.

19 Historiografia essa já tratada nos parágrafos anteriores.

20 VAINFAS, Ronaldo. Trópico dos pecados: moral, Sexualidade e inquisição no Brasil. - Rio de Janeiro: civilização Brasileira, 2010, pp. 29-75, 101-147. VAINFAS, Ronaldo. SANTOS, Georgina Silva dos. "Igreja, Inquisição e religiosidades coloniais". In: FRAGOSO, João \& GOUVÊA, Maria de Fátima. (orgs.). O Brasil colonial: volume 1 (ca. 1443- ca.1580). - Rio de Janeiro: Civilização Brasileira, 2014, p. 483. 
com as "raças impuras e infectas", assim como (2) ter um casamento extremamente arrumado que não fosse condenado pela Inquisição. Sob o primeiro ponto de vista, utiliza-se uma ideia que será desdobrada nesse tópico de várias maneiras: que o casamento "era uma opção das 'classes dominantes', motivado por interesses patrimoniais ou de status" ${ }^{21}$. Na segunda observação, os tipos de convivência em que a Igreja estaria de olho seriam o concubinato, o amancebamento e os casamentos costumeiros, que eram vigentes desde Portugal da Baixa Idade Média ${ }^{22}$. Em termos Inquisitoriais, a bigamia foi o crime que a instituição decidiu perseguir e punir os envolvidos ${ }^{23}$.

Como dito anteriormente, havia perseguição da Inquisição, mas inclusive da própria sociedade. Ora, se amancebar com negra, índia, ou casar-se com algum(a) descendente não era crime institucional. Não era proibido. Nem passível de ser degredado ou queimar na fogueira. Mas era uma prática que seria "condenada" pelos moradores dos trópicos ${ }^{24}$. Condenação paradoxal. Impossível dizer que todos os brancos se relacionaram sexualmente com africanas e índias, mas foi, de fato, uma prática comum a todos os espaços do Brasil Colonial ${ }^{25}$. Uma sedução, um aliciamento, uma "escapadela" poderia até mesmo ser aprovada por setores da sociedade colonial, a saber, a parte masculina misógina, que se valia da estrutura da escravidão para tais atividades; afinal, muitos senhores se inseriam nesse mundo “convictos da inferioridade dessas moças 'solteiras', boas para amar, indignas para se casar" ${ }^{\prime 2}$. Inclusive a Igreja e a estrutura monárquica deram algumas contribuições para essas aprovações ${ }^{27}$. Entretanto, a condenação que aqui se refere seria dos "frutos"

21 VAINFAS. Op. Cit., 2010, pp. 103-104. SILVA, Maria Beatriz Nizza da. Sistema de casamento no Brasil colonial. São Paulo: editoria da Universidade de São Paulo, 1984, PRADO JÚNIOR, Caio. Formação do Brasil contemporâneo: colônia. - $23^{\mathrm{a}}$ ed. São Paulo: Brasiliense, 2008. FARIA, Sheila de Castro. A colônia brasileira: economia e diversidade. - São Paulo: Moderna, 1997.

22 VAINFAS. Op. Cit., 2010, p. 110.

23 Citam-se aqui em especial os casos de bígamos em Alagoas, estudados por MOTT. Op. Cit., 2012.

24 VAINFAS. Op. Cit., 2010, p. 126. BOXER. Op. Cit., 2002.

25 PRADO JÚNIOR. Op. Cit., 2008, p. 271.

26 VAINFAS. Op. Cit., 2010, p. 127. VAINFAS, Ronaldo. "Moralidades brasílicas: deleites sexuais e linguagem erótica na sociedade escravista". In: MELLO E SOUZA, Laura de (org.). História da vida privada no Brasil: cotidiano e vida privada na América portuguesa. Coordenado por Fernando A. Novais. - São Paulo: Companhia das Letras, 1997, pp. 229-242.

27 "A política matrimonial da Coroa parece ter se guiado, com efeito, por razões de Estado, interesse no povoamento, manutenção da segurança e do controle mais do que por fidelidade à ética da Contrarreforma". Cf. VAINFAS. Op. Cit., 2010, p. 134. 
gerados desses relacionamentos: os filhos, ou um constante contato, inclusive vivendo "portas adentro"28. Caso fosse escancarado para todos os círculos sociais, a condenação poderia ser imediata: atentado à lei católica, desobediência de algum mandamento cristão, compactuação com as "raças impuras e infectas".

Adquirir esse estigma era algo que nenhum homem branco "poderoso" queria carregar, ou passar aos seus filhos ${ }^{29}$. Se habilitar ao Santo Ofício era uma estratégia de calar a sociedade, mas também uma chance de dar a Inquisição uma oportunidade de por sobre a mesa a suposta "mancha", no sangue ou no casamento do habilitando. Além de demonstrar poder aos outros "brancos", invariavelmente era uma prática que fez com que a pureza de sangue se perpetuasse cada vez mais. Tal como escreveu Jean-Louis Flandrin: “a história da família não pode ser escrita sem se ter em conta estas relações de boa - ou má - vizinhança, da vigilância pela comunidade (...), das suas intervenções na vida privada e da pressão muito forte que ela exercia sobre o comportamento de cada um"30. O casamento colonial tridentino era condição sine qua non de enraizamento estrutural do caráter racista da escravidão, aliado aos ideais nobiliárquicos de Antigo Regime ${ }^{31}$.

Muitos conseguiram burlar as leis e recriar os costumes hierárquicos da sociedade colonial até certo ponto ${ }^{32}$. Todavia, importa aqui lembrar que por mais que uma instituição tivesse em seus quadros um "sangue impuro", tão importante seria saber como a sociedade ao redor dele se comportava em relação a sua pessoa. Para o caso do Santo Ofício, as famas de "mourisco",

28 Expressão popular comum em vários documentos inquisitoriais, citada em todo momento por autores como Ronaldo Vainfas e Luiz Mott. Cf. VAINFAS. Op. Cit., 2010, p. 124.

29 Sobre os "poderosos" Senhores de Engenho do Recôncavo Baiano, cf. SCHWARTZ, Stuart. Segredos internos: engenhos e escravos na sociedade colonial, 1550-1835. - São Paulo: Companhia das Letras, 1988, pp. 225-231

30 FLANDRIN, Jean-Louis. "Familia". In: Le GOFF, Jacques. CHARTIER, Roger. REVEL, Jacques. (dir.) A Nova História. Coimbra: Almedina, 1990, p. 213.

31 "Não fosse pela pobreza ou reputação que infamavam tais concubinas, sê-lo-ia pela cor e progênie índia, mestiça ou negra, igualmente infamada no direito e nas tradições ibéricas da época moderna. Os que ousassem casar com negras, mulatas ou cristã-novas ficariam impedidos de concorrer aos quadros burocráticos da monarquia; ingressar nas Ordens Militares de Cristo, Aviz e Santiago; integrar o clero; obter vereanças nas câmaras municipais; associarse a certas irmandades, misericórdias, instituições de caridade e outras, além de igualmente bloquearem toda a sua descendência”. VAINFAS. Op. Cit., 2010, p. 114

32 Novos estudos se propõem atualmente a tratar essa inserção do negro dentro da sociedade colonial, burlando sistemas e se aproveitando de suas rachaduras para auferirem pontos de resistência, pactos e negociações no regime escravista. Cf. LARA. Op. Cit., 2005. MATTOS. Op. Cit., 2014. 
"mulato" ou de amancebamento com pessoas "de cor" impediram muitos colonos de ingressar na instituição ${ }^{33}$.

Pretende-se observar o casamento aqui não como algo pensado para o Santo Ofício, e sim como uma ferramenta social de estabelecimento na sociedade. Uma prática social comum na América portuguesa. Uma estrutura mental que ganhou força com a escravidão, no sentido de diferenciação, hierarquização e distinção social. Observar os matrimônios de alguns Agentes da Inquisição ajuda a complexificar a ideia de que, nem tudo que os Familiares faziam eram por causa da Inquisição. Cria-se, por conseguinte, uma perspectiva dialética na qual certas atitudes eram ações em prol do Tribunal (ou por medo); e o Santo Ofício, por sua vez, também foi utilizado como ferramenta de poder por parte dos luso-brasileiros.

Assim sendo, não se deve cair no erro de ilusão biográfica ${ }^{34}$. Uma natural da terra se casar com um reinol é uma opção. Dois brancos se casarem em uma sociedade escravista é outra posição. Mas, um reinol e uma natural da terra, brancos, se casarem pensando em promoção de status para ascender na sociedade, visando um cargo no Santo Ofício em um futuro é algo completamente diferente. Há uma relação de causa-e-efeito simples: só pode ser Familiar do Santo Ofício quem for "branco" e sem vestígio de "raça impura". Logo, todos os familiares do Santo Ofício em "Alagoas Colonial" serão "brancos" (ou pelo menos tratados como). Contudo, nada mais natural que em uma sociedade escravista, onde o negro e o ameríndio foram tratados como "raças inferiores e impuras" e que seus descendentes sofreram as discriminações sociais e raciais, os habitantes lusos e lusobrasileiros se casassem entre si, perpetuando os ideais de sangue do Antigo Regime. A partir disso, salienta-se que ninguém se casa para ser do Santo Ofício. As pessoas se casavam para criar, manter e perpetuar aparências sociais e materiais na sociedade em que viviam a partir da estrutura mental dominante naquela época e espaço ${ }^{35}$. Afinal, tão importante quanto os rituais e seus significados,

33 NOVINSKY, Anita. "A Igreja no Brasil colonial. Agentes da Inquisição”. AMP, XXXIII, 1984, p. 26-34. Apud VAINFAS. Op. Cit., 114.

34 Conceito elaborado pela crítica de Pierre Bourdieu. Cf. SCHMIDT, Benito Bisso. "História e Biografia". In: CARDOSO, Ciro Flamarion \& VAINFAS, Ronaldo. (orgs.) Novos domínios da história. - Rio de Janeiro: Elsevier, 2012, pp. 197-198. Ver também sua entrevista em Revista de História da Biblioteca Nacional, Ano 8, $\mathrm{n}^{\circ}$ 94, julho de 2013, pp. 52-57, em especial p. 56.

35 Dominante aqui se entende no sentido de que exercia poder contra outras opções que seriam contrárias a ela ou pusessem em risco sua hegemonia. Não se acredita que a "estrutura dominante" existia porque era "a melhor", e sim porque detinha meios de coerção e até mesmo violência para impor seus ideais perante outras classes 
"mais reveladores são os costumes da convivência entre os jovens e respectivas famílias antes e depois do compromisso (...)"36.

\section{2. Microcosmos da Inquisição.}

Uma relação curiosa, dentro da estrutura dos Familiares e Comissários do Santo Ofício, é a questão de famílias terem em seus quadros genealógicos, diversos agentes da Inquisição. Seja se casando, ou com parentes se habilitando ao mesmo tempo, ou em períodos próximos.

Alerta-se de imediato que tal ideia tratará por separar para avaliação os conjuntos familiares já estruturados pós-carta de habilitação do Santo Ofício. Ou seja, respeitam-se as disparidades temporais de casamentos entre membros da própria família, onde poderiam ter havido influência de algum membro para o outro se casar e, consequentemente, se tornar Agente da Inquisição. Contudo, preferiu-se selecionar e fechar todos os conjuntos já com suas respectivas habilitações, no intuito de garantir avaliações para poder traçar hipóteses de como certas atividades poderiam ser pensadas visando um fim (ter mais de um membro Familiar do Santo Ofício).

Dos 18 agentes do Santo Ofício em "Alagoas Colonial”, constatou-se que no carrossel dos casamentos e das habilitações acabou-se formando 05 famílias nas quais mais de um membro era Familiar ou Comissário do Santo Ofício da Inquisição de Lisboa. Dentro desses cinco conjuntos matrimoniais, encontram-se 14 dos 18 agentes do Santo Ofício em “Alagoas Colonial”. Portanto, veem-se no território “alagoano” verdadeiras famílias de agentes da Inquisição.

Tabela: Famílias da Inquisição em Alagoas (1674-1820) ${ }^{37}$

subalternas e até mesmo as culturas populares que se reinventavam a partir da conexão com a "dominante", assim como resistiam em relação a essa última. Cf. GINZBURG, Carlo. O queijo e os vermes: o cotidiano e as ideias de um moleiro perseguido pela Inquisição. - São Paulo: Companhia das Letras, 2002. Cf. BURKE, Peter. Variedades de história cultural. - Rio de Janeiro: Civilização Brasileira, 2000, pp. 233-267. Cf. BURKE, Peter. "Pensador polivalente". Entrevista por Bruno Garcia e Janine Justen. In: Revista de História da Biblioteca Nacional. Ano 9 , $n^{\text {o }}$ 102, Março 2014, pp. 52-53. MARX, Karl. ENGELS, Friedrich. A ideologia alemã. Organização, tradução, prefácio e notas de Marcelo Backes. - Rio de Janeiro: Civilização Brasileira, 2007, p. 71.

FLANDRIN. Op. Cit., 1990, p. 212.

37 Fonte: ANTT. Tribunal do Santo Ofício. Habilitações; cf. ROLIM, Alex. "Mercadores da inquisição. Notas sobre 


\begin{tabular}{|c|c|}
\hline FAMILIAS & NÚMERO DE AGENTES \\
\hline $\begin{aligned} \text { Correa da Paz } & \text { - Araújo } \\
& \text { - Araújo Barbosa } \\
& \text { - Rabello Almeida }\end{aligned}$ & $\begin{array}{l}\text { Severino }(1674)^{1} \\
\text { Antonio }(1678) \\
\text { Constantino }(1683) \\
\text { Antonio }(1696) \\
\text { Agostinho }(1766)\end{array}$ \\
\hline $\begin{aligned} \text { Amorim Cerqueira - Araújo Lima } \\
\text { - Carvalho Monteiro }\end{aligned}$ & $\begin{array}{l}\text { João (1703) } \\
\text { Domingos (1709) } \\
\text { Manuel (1716) }\end{array}$ \\
\hline Lins Vabo & $\begin{array}{l}\text { João (1790) } \\
\text { Inácio (1790) } \\
\text { José (1790) } \\
\text { Pedro (1790) }\end{array}$ \\
\hline Bastos & $\begin{array}{l}\text { Joaquim (1818) } \\
\text { João }(1810)\end{array}$ \\
\hline Inácio de Lima - de Gusmão & $\begin{array}{l}\text { José (1765) } \\
\text { Pedro Jorge Monteiro (sem info.) } \\
\text { João Friz[?] Vieira[?] (sem info.) }\end{array}$ \\
\hline Lemos Barbosa & Gonçalo (1716) \\
\hline Lemos Ribeiro & André (1773) \\
\hline Sampaio & Gabriel (1808) \\
\hline Alves de Barros & Francisco (1820) \\
\hline
\end{tabular}

Essa questão de data e habilitações simultâneas pode ter sido reflexo do enraizamento da Inquisição na sociedade portuguesa e luso-portuguesa nos Trópicos. É bem fundamentada a visão historiográfica de que a Inquisição portuguesa já estava debilitada nos períodos finais do XVIII e começo do $\mathrm{XIX}^{38}$. Não se sabe, de modo geral, um período mais ou menos específico onde famílias inteiras e de uma só vez se habilitassem para os cargos do Santo Ofício. Pelo menos para "Alagoas Colonial" têm-se os irmãos Pedro, Inácio, José e João Vabo se habilitando ao mesmo tempo em 1790, enquanto os irmãos João e Joaquim Tavares de Bastos, que vieram de Portugal, se habilitaram simutâneamente entre 1803-1808.

Tais informações podem garantir diversas interpretações e hipóteses de estudo. Inclusive é deveras importante salientar que o cargo do Santo Ofício era vitalício, mas não perpétuo, nem hereditário e muito menos venal. A existência de vários parentes, em ambos os ramos da família,

estratégias de ascensão social (Alagoas Colonial, c. 1674 - c. 1820)”. Historien (Petrolina). Ano 4, nº 9. Jul/Dez 2013, pp. 346-365. Acessado em www.revistahistorien.com

38 Opinião comum para Aldair Rodrigues, Daniela Calainho, Ronaldo Vainfas, Francisco Bethencourt e José Veiga Torres. 
inseridos na Inquisição é completamente diferente de uma estrutura parecida ser aplicada aos cargos administrativos e militares, por exemplo, como foi bem estudado - e continua sendo - por Dimas Marques $^{39}$.

Um dos primeiros pontos a ser complexificado é a clássica conclusão da "limpeza de sangue": habilitar-se ao Santo Ofício significava limpar o sangue da família de qualquer vestígio de judeu, africano e/ou ameríndio. Se isso era bem visado, qual a motivação de pessoas da mesma família habilitarem-se ao decorrer dos anos?

O ponto principal para se partir aqui é que a limpeza era feita "para trás". Limpavam o sangue do habilitando, da esposa (se fosse casado), assim como dos irmãos, dos pais, dos avós e dos bisavós. Se um irmão limpo se casasse com uma cristã-nova e tivesse um filho, provavelmente a Inquisição não consideraria o sobrinho do habilitado como uma pessoa de sangue puro. Além do mais, estudando as habilitações em separado, pode-se verificar melhor essa dinâmica do carrossel inquisitorial.

Contudo, mesmo os Familiares tendo prestígio e usando-o a seu bel prazer, arbitrariamente, ou apenas simbolicamente sem uso da força, ou causando transtorno, vários foram os casos de agentes da Inquisição que eram "injuriados” pela população local, não pelo seu comportamento como Familiar, mas pela sua condição de sangue e fama: nesse caso, cristãos-novos ou mulatos. Já foi afirmado que a "pureza de sangue" era condição sine qua non para que uma pessoa se tornasse agente da inquisição, principalmente antes das reformas pombalinas. Veiga Torres apontava que a passagem de um cristão-novo pelas malhas da inquisição era quase impossível, visto o rigor que existia em relação à "pureza de sangue" nos quadros das entrevistas e construções genealógicas. Todavia, Familiares no Brasil foram constantemente chamados de mulatos ou de cristãos-novos, tanto pelas más-linguas da sociedade, como pelos inimigos e detratores ${ }^{40}$.

Esse primeiro apanhado de ideias serve para criar base de sustentação para o que seguirá adiante. O fator "sangue impuro" esteve sempre presente nas conversas de famílias que pretendiam manter sua linhagem "livre de infecta nação". A partir de estudos de caso, observar-se-á como o aparecimento de negros(as) e pardos(as) receberam diferentes olhares pela Inquisição, assim como

39 MARQUES, Dimas. "Por meus méritos às minhas mercês". Elites administrativas e a distribuição de cargos (Comarca das Alagoas - século XVII-XVIII). Universidade Federal de Alagoas, Instituto de Ciências Humanas, Comunicação e Artes, Departamento de História, Monografia: Maceió, 2011. 
pela população local, que misturavam aspectos como "baixa condição" e "utilidade no serviço". Com isso, pode-se hipotetizar diferentes visões sobre os negros e a partir deles.

\section{3. Habilitação negada por envolvimento com negra escrava.}

Em 1755 ocorreu na Vila das Alagoas uma diligência para habilitação de Familiar do Santo Ofício. O requerente era Antonio Pinto Nogueira, natural da Vila de Amarante, Bispado de Braga e morador na Vila das Alagoas, Capitania de Pernambuco. Vinha de família "limpa" de sangue e relativamente honrada, tendo inclusive sido estudante na Sacristia de São Gonçalo com os religiosos Dominicanos, em Portugal. Fora ainda menor de idade para "os Brasis e terras de Pernambuco". Casou-se com Maria José, natural e moradora na Vila das Alagoas, filha de pessoas importantes e "ilustres" nos quadros sociais da vila, pois eram limpos de sangue ("sem mistura"), brancos, cristãos velhos, que tinham ocupado os cargos nobres da República (ou seja, a Câmara Municipal), assim como postos de Capitães Mores da Ordenança e Clérigos "competentes". Sua riqueza estava avaliada em viver de fazendas e de um Engenho de Açúcar ${ }^{41}$.

Isso teria sido o suficiente para Antonio Pinto Nogueira se habilitar sem impedimentos ao cargo de Familiar do Santo Ofício. Economica e politicamente era um "fiel vassalo" do Rei católico de Portugal ${ }^{42}$. Contudo, sua vida social nos Trópicos deixou muito a desejar aos Comissários encarregados nas diligências. Apesar de Maria José ter sido sua primeira e única mulher, Antonio Pinto Nogueira não se conteve nos ímpetos misóginos e sexuais da América portuguesa escravista, pois antes de se casar tivera dois filhos ilegítimos com uma escrava mestiça que ele mesmo forrara que se achava ausente nas partes da Bahia. Depois de consumado o casamento com Maria José, se

41 Maria José era filha de António Correia Dantas e de Madalena Pais; neta paterna do capitão mor Miguel Correia Dantas e de Isabel de Amorim; e materna de Manuel Cardoso Rego e de Ana Correia Pais, todos naturais e moradores em Alagoas. ANTT. Tribunal do Santo Ofício. Conselho Geral. Habilitações incompletas. Maço 17, doc. 677.

42 No resumo da entrevista, as informações principais são: "boa reputação no procedimento, vida e costumes, tem vivido limpamente, e com tratamento nobre de seus cavalos de estada na estribaria, e os aprestos[?] necessários para o uso deles, e a esse respeito fora admitido a servir os cargos honrosos da Republica de Almotacé, vereador, e Juiz Ordinario, e a sua vivenda era de lavrador de canas com suas fábricas, tendo mais parte de um engenho de água de fazer açúcar, moente e corrente, que lhe veio de dote, ou legitima de sua mulher Maria José com quem hé casado, e está fazendo vida marital; e possuira de seu cabedal melhor de dez mil cruzados, saber ler e escrever". Cf. Idem. Maço 17, doc. 677. 
relacionou com outra escrava (já defunta em 1755), com quem tivera oito filhos, "entre machos e fêmeas", das quais uma foi forrada pela própria Maria José, enquanto que ele forrara um "macho", deixando todos os outros seis ainda cativos e sujeitos à escravidão ${ }^{43}$.

Relacionamento com negras não impediram Antonio Pinto Nogueira de conseguir se habilitar ao cargo de Santo Ofício. O aspecto principal da negação foi as uniões ilícitas e filhos ilegítimos. Todavia, procura-se esse aspecto duplo da classificação dos africanos e descendentes (mestiços ou não) na América portuguesa. Tanto pelo prisma da Inquisição como pelas relações culturais criadas e transformadas na conquista americana. A relação de concubinato é importante para entender processos de aculturação e da relação de homens brancos com mulheres negras, índias ou mulatas, onde muitas vezes não faltava o estigma da escravidão e nem as relações patriarcalistas exacerbadas $^{44}$.

\section{4. Habilitação onde houve acusação de parentesco com pardo.}

O estigma de ser descendente de africano, ou de ter uma parcela, mesmo que ínfima, de seu "sangue", atormentava aqueles que buscavam uma vida fidalga nos espaços rurais e urbanos da América portuguesa, desejando uma vida social de prestígio e poderes elevados. Tormento duplo: fofocas e fuxicos locais sobre suas "qualidades" ou casos mais incisivos como a não participação de postos militares, cargos da Câmara Municipal, Ordens religiosas e outros ofícios administrativos.

José Inácio de Lima era Senhor de Engenho de Açúcar, dono de escravos e com cabedal de cerca de 20 mil cruzados, inclusive sem dívida com ninguém. Tinha 28 anos quando se foi

43 Idem. Maço 17, doc. 677.

44 VAINFAS. Op. Cit., 1997, pp. 229-242. Em Portugal continental, Fulana analisou processos de negação de habilitação do Santo Ofício entre 1684 e 1725, onde o quesito do amancebamento com mulheres negras foi fator chave para impedimento de merecimento do título. Entre "Seis candidatos a familiares [de124] eram cristãos velhos mas o cônjuge tinha ascendentes negros, dois outros, também cristãos velhos, viram frustradas as suas pretensões pois um vivia amancebado com uma escrava e outro tinha trato com uma negra que estava "prenhe". Isto é, na fonte em estudo os habilitandos ou seus cônjuges tinham alguma parcela de sangue negro ou, pontualmente, algum relacionamento condenável com negras". BRAGA, Isabel M. R. Mendes Drumond. "A mulatice como Impedimento de acesso ao “Estado do Meio"”. In: Actas do Congresso Internacional Espaço Atlântico de Antigo Regime: poderes e sociedades. Lisboa, 2 a 5 de Novembro de 2005, p. 5 . Texto acessado em 09/05/2014, às 20:33:03. Em http://cvc.instituto-camoes.pt/eaar/coloquio/comunicacoes/isabel_drumond_braga.pdf 
habilitado com a medalha e o cargo de Familiar do Santo Ofício em 5 de julho de 1765. Era natural de Porto Calvo, tendo sua família inteira naturais e moradores no mesmo espaço ${ }^{45}$. Casado por sua vez com Dona Luzia Francisca de Gusmão, natural de Recife ${ }^{46}$.

A inquirição aconteceu em 1763, na área toda circunscrita da Vila de Porto Calvo. Ou seja, envolvendo também Camaragibe, São Bento, Unna e Ipojuca. Neles foram entrevistadas pessoas para responderem as questões relacionadas a família de José Inácio de Lima.

De acordo com as testemunhas, os avós paternos Antonio de Freitas Costa e Leandra Lopes de Lima eram conhecidos como lavradores de Cana de Açúcar, sendo que no ano de 1763 o avô paterno já era falecido. Em Ipojuca um dos entrevistados ouvira falar que "Fulano da Costa Freitas", pois não sabia se era Antonio ou João, era branco, mas tinha um rumor de não saber se era cristão velho, sendo morador no lugar de Utinga, distante umas léguas do Engenho de Tabatinga de Ipojuca, onde a testemunha morava, e que o lugar de Utinga já pertencia à freguesia do Cabo. Continuava dizendo que "Fulano de Freitas da Costa" não teve ocupação nenhuma em sua vida, pois vivia de mandar serrar madeira a partir do trabalho de seus escravos. A maioria dos entrevistados de Ipojuca não conheciam os avós, portanto, não davam nenhuma informação. Um dos inquiridos dissera apenas que nunca tinha ouvido algum rumor difamatório sobre Antonio de Freitas da Costa e Leandra Lopes.

Sobre os avós maternos, Matheus Gomes e Luiza da Fonseca, poucas informações, já que poucas pessoas os conheciam. Alguns alegavam que o Avô era escultor de imagens religiosas. Um dos entrevistados disse que não conhecia os avós maternos, mas sabia por ter escutado que o Engenho em que o José Inácio morava tinha sido "uma graça recebida pelos seus avós". Em Camaragibe, um dos entrevistados dizia que Matheus Gomes ainda tinha dois filhos sacerdotes, Álvaro Martins e Clemente "de tal”; outro entrevistado alegava que Matheus Gomes tinha parentescos com uns Prados[?] $]^{47}$.

45 Declarava José Inácio de Lima ser filho legítimo de Paulo de Freitas da Costa e de sua mulher Isabel Gomes da Fonseca, ambos naturais da freguesia da vila de Porto Calvo. Neto paterno de Antonio de Freitas da Costa, natural da dita vila de Porto Calvo e de sua mulher Liandra Lopes de Lima, natural da freguesia de Ipojuca do mesmo distrito. Neto materno de Matheus Gomes natural da freguesia de Camaragibe distrito da dita vila de Porto Calvo, e de sua mulher Luiza da Fonseca, natural da dita freguesia da vila do Porto Calvo.

46 ANTT. Tribunal do Santo Ofício. Conselho geral. Habilitações. José. Maço 103 - doc. 1465

47 Esse é um dos maiores problemas da documentação do Santo Ofício. A fala do entrevistado e a transcrição do Comissário. Nesse caso, Prado seria um sobrenome ou uma grafia para "Pardos"? Leva-se a crer que o entrevistado 
Ter parentesco com pardo era uma situação séria para o Santo Ofício, passível de negação da habilitação e da medalha para o requerente, por mais branco e "honrado" que ele fosse. O rumor de não ser cristão-velho também era suficiente para dinamitar qualquer pretensão de cargo da Inquisição além de expor para toda população uma comprovação de sangue judeu.

Após a chegada do Marquês de Pombal ao poder, que trouxe mudanças drásticas na história de Portugal, somente em 1774 é que se extinguiu a distinção de Cristãos Velhos e Cristãos Novos nos estatutos do Reino, inclusive da Inquisição de Portugal ${ }^{48}$. Assim, fez-se com que as pesquisas genealógicas para se tornar familiar não tivessem mais o fator "sangue judeu" como algo que impedisse a habilitação. Contudo, os "sangues infectos" de negros, mouros e de outras "raças" ainda faziam parte dos preconceitos raciais da Inquisição. Eram fatores que negavam a chegada de um habilitando ao cargo de Familiar ${ }^{49}$. Em 1763, o ideal seria que os Comissários da Inquisição, encarregados de verificar essas informações, rodassem praticamente o Atlântico inteiro para tentar comprovar ou desmentir essa descendência judaica (e quem sabe a "prática") e as relações de parentesco com pessoas pardas.

Essa ideia se baseia no fator prova concreta. Os rumores podem ter sido documentados, mas não levados a sério pelo Comissário, visto a quantidade de pessoas para cada rumor: uma alegação do avô materno ser possivelmente cristão-novo, e outra sobre o avô paterno ter parentesco com alguns pardos. Não havia provas cabais. E mesmo assim, enquanto um dizia "rumores", outros faziam questão de expor que não existiam "rumores difamatórios" sobre a pessoa inquirida e sua família. Alguns estudiosos podem alegar que apenas um rumor seria o suficiente para se abrir um processo de denúncia. Contudo, pensa-se aqui que a necessidade de tal ato já era automaticamente

quis dizer "pardo", por conta da importância que o mesmo quis dar dessa observação, e que o Comissário pode ter grafado erroneamente como "prado".

48 “O Tribunal do Santo Ofício, também conhecido como Inquisição, sofreu rudes golpes com a reforma pombalina que o equiparou a qualquer outro tribunal régio. Deixou de ser um órgão especializado na perseguição dos cristãosnovos para actuar, de uma maneira ampla, na defesa da religião católica. Não escapam das suas teias feiticeiros, blasfemos, curandeiros, sodomitas, bígamos e hereges de ambos os sexos, a maior parte provenientes das camadas mais humildes da população". LEONZO, Nanci. “As instituições”. In: SILVA, Maria Beatriz Nizza da. (coord). Nova História da Expansão Portuguesa: O império Luso-brasileiro (1750-1822). Direcção de Joel Serrão e A. H. Oliveira Marques. - Lisboa: Editorial Estampa, 1986, p. 314.

49 RODRIGUES. Op. Cit., 2007, p. 93. BOXER. Op. Cit., 2002, pp. 278-279: "Nem Pombal, nem seus sucessores tinham a intenção de abolir a escravidão nas possessões ultramarinas, onde tanto a legislação como os costumes sociais continuavam a discriminar as pessoas de sangue negro, fossem indivíduos livres ou escravos". 
cancelada pela própria natureza da inquirição de habilitação para Familiar do Santo Ofício. As próprias testemunhas que falavam bem de José Inácio de Lima seriam as mesmas que inconscientemente livrariam seus avós de qualquer crime difamatório e, possivelmente, o cancelamento do hábito de familiar para José Inácio. Portanto, fofocas difamatórias existiram, por isso, não houve um completo erro de genealogia ou um desleixo do Santo Ofício em relação a essas possíveis acusações. Elas apenas foram derrubadas mediante o fluxo que as entrevistas tomaram. Pode-se afirmar que o processo de habilitação para Familiar do Santo Ofício de José Inácio de Lima acabou sendo, no limite, ao mesmo tempo, um processo de averiguação de criptojudaísmo de seu avô paterno e de parentesco com pessoas de "raça impura" de seu avô materno. Tornando, assim, o exercício da inquisição desleixado em alguns pontos, mas bem práticos em outros.

\section{5. Pardos e forros como testemunhas do Santo Oficio.}

Sobre as testemunhas, têm-se pardos e forros que contribuíram para manutenção da polícia da Inquisição nos territórios da Vila das Alagoas. Volta-se ao caso de José Inácio de Lima, Senhor de Engenho em 1763, cujo avô materno foi acusado informalmente de ter parentesco com "alguns pardos" ${ }^{\circ 0}$. A acusação partiu de José Ribeiro da Silva, homem que vivia de suas agências, casado, natural e morador "do lugar do vermelho", freguesia de Ipojuca, "tido e havido por branco", não informando sua idade.

A partir desses dizeres "tido e havido e branco", seria normal desconfiar e delatar ao Santo Ofício o parentesco com alguns pardos, do qual o avô do habilitando era acusado. "Pardisse" naquela época, na região de Porto Calvo, pelo que foi observado não era tão bem visto, uma vez que essa é a única inquirição em que tal ponto de estratificação social e discriminação por cor é tão martelado pela população ${ }^{51}$. Seja em sentido acusatório ou de auto-promoção ao Santo Ofício, como se sua "brancura" fosse distintivo para validar seu depoimento como algo "fidedigno".

Dos oficiais mecânicos entrevistados, têm-se Antonio Tenório da Silva, casado, Oficial de Carpinteiro, morador e natural da freguesia de Ipojuca, homem pardo, de 76 anos. Surpreendentemente foi o único a se manifestar a favor de Antonio de Freitas da Costa e Leandra Lopes, informando que "nunca ouviu rumor difamatório" sobre o casal. Ironicamente, foi um

50 ANTT. Tribunal do Santo Ofício. Conselho geral. Habilitações. José. Maço 103 - doc. 1465.

51 Todos se dizem "brancos e cristãos-velhos", reafirmando, portanto, suas condições sociais. 
homem de "sangue manchado", de cor "impura", de ocupação com "ofício vil", que praticamente pode ter salvado os avós do habilitando da acusação de parentesco com pardos e cristãos-novos dadas por um Capitão branco Senhor de Engenho, o Capitão Ambrósio Machado da Cunha, Senhor do Engenho da Guerra, freguesia de Ipojuca, onde era morador. Dizia-se casado, branco e de 62 anos.

De todas as documentações vistas até o momento, essa é a única que tem uma "acusação" nos depoimentos. Pelo visto, os Senhores de Engenho, comerciantes e lavradores de cana muitas vezes não eram pacíficos entre si. Plantar a semente da "cristã-novisse" e das relações com pardos era uma boa maneira de limar e humilhar publicamente uma pessoa. Típica de uma sociedade estritamente católica e escravista de raízes ibéricas medievais.

A primeira inquirição para o cargo de agente do Santo Ofício em "Alagoas Colonial" se deu em 1674, com Severino Correa da Paz $^{52}$. Daquela data até 1763 (José Inácio de Lima), nenhum pardo tinha aparecido como testemunha, sendo todos "brancos e cristãos-velhos". No entanto, isso não pode ser entendido como uma viragem estrutural, visto que os próximos pardos e pardas só aparecerão como testemunhas em 1803-1807, durante as inquirições sobre a vida do homem de mercancia Joaquim Tavares Bastos e sua mulher Ana Felícia de Jesus, moradores da Vila das Alagoas, ele português e ela "alagoana",53.

Os pardos eram Antonio João Correa, de 58 anos, que vivia do seu ofício de alfaiate, e Inácio José do Nascimento, casado, 62 anos, que vivia de ser procurador de causas nos auditórios da mesma Vila das Alagoas. No círculo feminino, o Santo Ofício entrevistou Luzia de Chaves, solteira, 74 anos, que vivia de suas agências, e Francisca Josefa de Albuquerque, sem indicação de estado religioso (solteira, casada ou viúva), de idade de 65 anos e que também vivia de suas agências.

A título de ilustração, fugindo um pouco do espaço "das Alagoas", mas ainda na região sul de Pernambuco, em Serinháem, a inquirição para habilitação de João Batista Acioly Lemos é deveras interessante no quesito dos pardos que aparecem como testemunhas, além de suas inúmeras

52 ROLIM, Op. Cit., 2013.

53 Tribunal do Santo ofício. Conselho Geral. Habilitações. Joaquim. Maço 21 doc. 262. Joaquim Tavares de Basto, português que veio a Brasil nos finais do século XVIII como jovem menor de idade e em 1803 já tinha 25 anos, sendo um homem de negócio e grandes cabedais. Começou a habilitação solteiro. No processo se casou e teve uma filha, o que alargou as inquirições por mais alguns anos. 
ocupações $^{54}$. Tendo acontecido em 1799, nos locais das três vilas, viu-se pardos e pardas de diferentes condições sociais, de idades entre 28 e 98 anos, vivendo das próprias mãos e até mesmo de Senhor de Engenho. Variavam de atividades açucareiras como purgador do açúcar, até às econômicas, como dono de agências, passando inclusive pelas profissões manuais de alfaiate e oficial de tanoeiro, somando com administrativas como oficial de justiça. Dos 16 pardos que se apresentaram apenas um se diz "livre", sendo ele Luis Pereira de Barros, natural e morador na freguesia de Camaragibe, no Engenho de Lucena da mesma freguesia, onde nasceu e morou até aquele presente. Com idade de 80 anos, pardo, livre, casado e que vivia de suas lavouras. Não se sabe se Luis Pereira de Barros foi o único ex-escravo, ou se tantos outros pardos esconderam uma possível antiga condição se denominando apenas "pardo" ou "parda", sem vínculo nenhum com a escravidão.

\section{6. Denúncia feita por mulato e negra:}

Se na metade do século XVIII, e depois no século XIX, os pardos e pardas aparecem como testemunhas valiosas nos processos de habilitação a algum cargo do Santo Ofício, é de se pensar até que ponto seus aparecimentos estão ligados a um mundo já altamente miscigenado (mas não menos racista), como era o espaço açucareiro do sul de Pernambuco ${ }^{55}$. Visto que para as primeiras

54 "Declara o suplicante ser filho do Capitão Antonio Franco da Silveira e D. Anna Francisca Achioly naturais da freguesia de Camaragibe do Porto Calvo. Neto paterno do Capitão Mor Manoel de Barros Franco e D. Anna Cavalcante de Mello, naturais da freguesia de Camaragibe do Porto Calvo, Bispado de Pernambuco, e moradores na Vila de Serinhaem, ela natural. Neto Materno do Mestre de Campo Antonio Luiz da Cunha, e D. Adrianna Vanderlei Lins naturais ele da freguesia de Camaragibe do Porto Calvo, e ela da Vila e Freguesia de Serinhaem tudo bispado de Pernambuco". Durante as diligências se descobriu que nenhum membro da família era de Porto Calvo, e sim que a maioria era de Serinhaém e Unna, o que pode ter causado confusão por conta das jurisdições militares e territoriais que aconteciam entre as três vilas. Tribunal do Santo Ofício - Conselho Geral - Habilitações - João Maço 170 - doc. 1476. Sobre a relação Porto Calvo, Serinhaém e Unna, cf. ROLIM, Alex. "Jurisdição militar, inquisitorial e territorial no sul de Pernambuco: Contribuição a uma arquitetura dos poderes nas Capitanias de Porto Calvo, Alagoas e Rio de São Francisco (1655-1712)”. Revista Ultramares. № 2, Vol. I, Ago-Dez/2012, Acessado em http://www.revistaultramares.com/ em 23/03/2013.

55 Em um âmbito geral, Luiz Mott escreveu que "diversos amos e senhores foram denunciados ao Santo Oficio por seus escravos, sobretudo por sodomia e judaísmo". Cf. MOTT, Luiz. "Cotidiano e vivência religiosa: entre a capela 
inquirições, eles são praticamente "inexistentes".

Nesse caso, é importante perceber até que ponto eram tratados como pessoas de depoimentos “fidedignos". Um exemplo é dado por uma denúncia feita a um Familiar do Santo Ofício na Vila das Alagoas, Antonio de Araújo Barbosa ${ }^{56}$, em 26 de fevereiro de 1708, sobre um Capitão, que junto com sua esposa, Cristã-nova, abusava fisicamente de seus escravos, além de não garantirem enterros ou outras atividades cristãs ${ }^{57}$. Este trabalho não se aterá sobre as atividades "judaicas" dos acusados. A questão dos maus-tratos deve ser salientada, pois seriam tais ações que possivelmente teriam feito um mulato e uma negra escrava dos dois senhores acionar o Santo Ofício. De acordo com as denúncias, o Capitão tinha raiva de um negro, que pertencia a Antonio Fariaz[?], que fez questão de comprá-lo para, em uma Sexta Feira da Paixão, açoitá-lo de uma maneira "que só os judeus os fariam em tal dia", tendo depois cortado suas orelhas e dá-las a um cão. A sua esposa, de "tão mal cristã", prendeu um escravo em uma corrente e o tinha mandado ingerir "um caldo quente fervendo", enquanto uma mulata deveria açoitá-lo até fazê-lo "expirar", sem confissão e sem sacramento. Era conhecido o casal por enterrar seus escravos em buraco nos campos, sem mortalha, encomendas ou qualquer ritual cristão.

Quem justificava tais ações era um mulato chamado Ludovico, e uma negra escrava por nome de Tecla[?]. Contudo, isso não seria suficiente para o Familiar encarregado da denúncia, que possivelmente não poderia confiar plenamente em duas pessoas "de raça de infecta nação", cuja condição social estava associada a todo tipo de atividade vil e desonesta nos espaços urbanos e rurais. Para isso, o agente do Santo Ofício se valeu ainda da confirmação dos fatos a partir do Alferes João Pires de Carvalho, de sua mulher Aurea de Coutto, do Reverendo Padre Joseph de Faria Franco, de Domingos Pereira Barbosa, do Capitão Balthazar[?] Coelho[?] Falcão[?], do Capitão Antonio do Coutto, de Christovão Moreira e sua mulher, e todos os moradores da freguesia de Santa Luzia da Lagoa do Norte.

e o calundu”. In: MELLO E SOUZA (org.). Op. Cit., 1997, p. 202.

56 Português, comerciante, casado com Mariana de Araújo, irmã de Antonio Correa da Paz e sobrinha de Constantino Correa da Paz. Sobre o estudo desse familiar e da família citada, cf. ROLIM. Op. Cit., 2013.

57 ANTT. Tribunal do Santo Ofício. Inquisição de Lisboa, Caderno do Promotor, livro 324, fls. 115-115v. Retirados de http://digitarq.dgarq.gov.pt/. Agradeço a professora Márcia Eliane de Souza e Mello da Universidade Federal do Amazonas por ter me entregue os downloads dos fólios digitalizados e a referência completa. A leitura e interpretação são de inteira responsabilidade minha. 
Atentando ao final da denúncia, tem-se que o Familiar só se importava com apenas um tipo de crime: violências contra a cristandade e à imagem de Jesus Cristo (que tinha sido tocado fogo em uma das noites de fúria do Capitão). É cedo para se arriscar uma possível insensibilidade em relação aos escravos, cujas ações deveriam pertencer à justiça secular e eclesiástica. Castigar e matar escravos não era crime de alçada da Inquisição, muito menos ir atrás de quem enterrava negros sem sacramentos e rituais católicos. Todavia, isso não deixa de ser menos importante aqui quando se analisa o prisma do mulato Ludovico e da negra Tecla, que tentaram ao máximo juntar duas acusações para fazerem prevalecer suas ações de poder. Afinal, os abusos contra negros e escravos andavam juntos com - de acordo com os dois - pensamentos e atitudes típicas de judeus em relação aos cristãos (batizados, mas não necessariamente cristãos). A carta na manga era juntar as violências físicas do casal "judeu” com sua predisposição às atitudes anti-cristãs; e o único argumento que conseguiram para "sensibilizar" o Familiar do Santo Ofício (tentar, pelo menos), foi o relato das mortes injustas e desnecessárias dos escravos sendo acompanhadas de enterros desrespeitosos com a tradição e religião católica romana.

Veem-se então dois pontos: 1) o conhecimento dos costumes locais que eram impostos pelos luso-brasileiros católicos sobre os escravos e seus descendentes, sendo usados por esses últimos como discursos de poder para se proteger daqueles que em muitos momentos os perseguiram. Não significaria uma manutenção passiva do sistema, mas uma atividade ativa de resistência; 2) o Santo Ofício, como instituição hierarquizadora e seguidora litteralis dos estatutos de limpeza de sangue, em vários momentos desclassificará depoimentos, vidas e atitudes de pessoas das classes de baixa condição, tanto pela cor como pelas condições sociais, pretendendo enrijecer os costumes de dominação escravista na sociedade.

\section{Perseguição.}

No tópico anterior pode ser vista a ideia de que o negro, ameríndio e seus filhos (miscigenados ou não) eram classificados pela Inquisição portuguesa como descendentes de raça de "infecta nação". Tornando-os "impuros" para os padrões de limpeza de sangue que vigoravam no Portugal continental. Foram do mesmo modo avaliados como peças importantes nas habilitações e nas denúncias de crimes que a Inquisição perseguia, apesar de não serem consideradas pessoas "fidedignas". Tinham dupla face para os brancos: pessoas mal vindas à família, mas bem vindas às 
ajudas $^{58}$. Assim como os próprios mulatos e negros igualmente viam na Inquisição uma moeda: instituição de classificação dominante e ferramenta para se usar e exercer poder contra aqueles que os oprimiam.

A seguir, observar-se-á situações nas quais a perseguição contra os negro, os pardos e os mulatos foi mais forte. Nestas os preconceitos raciais e sociais aparecem com maior intensidade nos discursos. Momentos em que a manutenção da ordem estava atrelada ao desejo de controle e repressão utilizada pela parcela "branca e pura" da sociedade.

\section{1. Negro Feiticeiro}

A perseguição não se encontra apenas na documentação produzida pelo Tribunal Inquisitorial. É possível encontrar pistas e casos em outros documentos de natureza diversa. Nesse sentido, observa-se aqui um requerimento feito para o Conselho Ultramarino em 1757, do Padre Caetano de Dantas Barros, que fora vigário da vara na freguesia de Nossa Senhora do Rosário na Vila de Penedo, Comarca das Alagoas. Seu pedido solicitava que lhe pagassem os ordenados que lhe deviam do tempo que atuou na Vila ${ }^{59}$. Dentro da documentação a situação se destrincha de maneira mais cuidadosa.

Tendo atuado de 1720 até 1746 na Vila do Penedo, o padre foi participante de inúmeras situações. Uma relatada no documento é de interesse aqui. Atuou junto com o Ouvidor da Comarca das Alagoas, Antonio Rabello Leite, na prisão do negro Salvador Pacheco. Era tido como "o maior feiticeiro" e de personalidade "insolente", pois mantinha em "casa pública" muitos "negros, negras e mulatos", ensinando a todos as práticas de feitiços, assim como mandingas e "dando ventura" a eles $^{60}$. O padre insinuava ainda que muitas mortes de "escravos" eram frutos das atividades de

58 SCHWARTZ, Stuart. "os escravos: <<remédio de todas as outras cousas $>>$ ". In: BETHENCOURT, Francisco. CHAUDHURI, Kirti. (dir.) História da Expansão Portuguesa vol. II: Do Índico ao Atlântico (1570-1697). Lisboa: círculo dos leitores, 1998. Sobre admoestação e disciplina mediante castigos, cf. ANTONIL, André João. Cultura e opulência no Brasil. Texto confrontado com o da edição de 1711; com um estudo biobibliográfico por Affonso de E. Taunay. $3^{\text {a }}$ ed. Belo Horizonte: Ed. Itatiaia; São Paulo. Ed. da Universidade de São Paulo, 1982. MAURO, Frédéric. Nova história e novo mundo. São Paulo: Editora Perspectiva, 1969. FERLINI, Vera. Terra, trabalho e poder: o mundo dos engenhos no Nordeste colonial. Bauru, SP: EDUSC, 2003.

59 Arquivo Histórico Ultramarino. Alagoas Avulsos. Documento 164.

60 As Constituições Primeiras do Arcebispado da Bahia, redigidas em 1707 e posta em prática no território do Estado 
Salvador Pacheco, "que tudo obrava alucinado pelo Diabo". Sua prisão foi feita e o mesmo foi remetido à Cadeia de Olinda, a pedido do Bispo Dom José Fialho, ali o negro deveria ser castigado, pois por sua culpa havia muitas mortes de escravos dos senhores na Capitania [do Rio de São Francisco $]^{61}$.

Destrinchar esse discurso é interessante. Do ponto de vista da perseguição, Salvador Pacheco pode ser considerado um negro realmente "insolente": Era professor de "práticas" extremamente condenáveis pela Inquisição, e ao se achar "em huma caza publica" traz à tona sua coragem de praticar sua religião em plena área urbana da Vila. A prisão ter sido efetuada pelo Eclesiástico e pelo Ouvidor indica a ação persecutória de denúncia a partir de outros habitantes. Tal como bem alertado por Laura de Mello e Souza feitiços e práticas mágicas poderiam ser usados para atos ofensivos (causar danos) como defensivos (preservação), principalmente entre desafetos nos espaços coloniais $^{62}$. Matar negros escravos de senhores (que poderiam ser poderosos) pode indicar Salvador Pacheco como um negro livre, que atacava a maior base de sustentação dos grandes poderosos da terra: sua escravaria. Provavelmente não era um ato de negro livre contra negro escravo, mas de um negro contra um senhor; levar em consideração que o "Feiticeiro insolente" ensinava seus feitiços e mandingas para outros negros e mulatos ajuda a indicar que suas ações não eram "alucinações do

do Brasil no decorrer dos anos, determinavam como alçada da justiça eclesiástica a capacidade de perseguir e aplicar penas espirituais a quem praticassem feitiçarias, superstições, sortes e agouros, assim como aqueles que tomavam "pacto com o demônio" para satisfazer seus interesses. Entre as penas estavam a excomunhão, degredo, punição física e pecuniária. $\mathrm{O}$ fato de tais crimes terem sido levados para alçada da Inquisição não será exposto nesse capítulo. Cf. VIDE, Sebastião Monteiro da. Constituições Primeiras do Arcebispado da Bahia. Estudo introdutório e edição Bruno Feitler, Evergton Sales Souza; Istvan Jancsó, Pedro Puntoni (organizadores). - São Paulo: Editora da Universidade de São Paulo, 2010, pp. 462-464. Título III do Livro V: Das feitiçarias, superstições, sortes e agouros. Como serão castigados os que usarem de arte mágica. Título IV do Livro V: Que nenhuma pessoa tenha pacto com o demônio nem use de feitiçarias; e das penas em que incorrem os que o fizeram.

61 AHU. Alagoas Avulsos. Doc. 164, fl. 5. O termo "Capitania do Rio de São Francisco" é comumente utilizado para designar o que atribui como sendo a região do Rio de São Francisco em direção aos Sertões, mas tendo como base institucional-jurídica a Vila de Penedo, pois lá estava a Câmara Municipal. Cf. ROLIM. Op. Cit., 2012.

62 MELlO E SOUZA. Op. Cit., 2009, pp.258-259. 
diabo" ${ }^{63}$ contra tudo e todos, mas direcionada contra uma classe: os senhores ${ }^{64}$.

Não se tem notícia ainda do seu processo ou denúncia em algum caderno do promotor ou outro conjunto documental nos arquivos Inquisitoriais ${ }^{65}$. O que importa realçar, com que se tem aqui, é esse aspecto auto-reprodutivo da atitude classificação $\rightarrow$ perseguição $\rightarrow$ classificaçãorenovada. Utilizando o que se chama hoje de Economia do Dom ${ }^{66}$, o Padre Dantas Barros fez questão de dizer ao seu Monarca católico as suas ações em prol do bem comum na sociedade, para assim receber sua graça e ter seu pedido acatado. Para isso, valeu-se do exemplo de Salvador Pacheco, trazendo a lume uma classificação comumente utilizada nos espaços da América: "insolente"; para depois arranjar-lhe uma nova, a partir de suas ações pessoais: "alucinado pelo diabo". Aglutinou para manter a imagem do negro como desobediente da ordem social (indisciplinado) e da moral católica (pactuador com forças demoníacas). Salvador Pacheco, por sua vez, não tem direito de defesa no documento redigido.

\section{2. Crioula das Superstições.}

Outra acusada de atividades nada ortodoxas foi uma crioula forra chamada Mariana, que ensinava orações de superstições para outras mulheres nos espaços da Vila das Alagoas, sendo uma Dona Paritis[?] $]^{67}$. Nada sobre o processo pode ser relatado, visto que é documento produzido por

63 A referência feita pelo padre ao "diabo" pode ser melhor matizada, o que não pode ser feito nesse texto. Todavia, por conta do recorte tomado e do espaço para materializar as ideias, sugere-se a leitura de SANTOS, Irinéia M. Franco dos. "A Caverna do Diabo: O ensaio romântico de Valeriano De Souza e as religiões afro-brasileiras em Alagoas, no séc. XIX". Sankofa. Revista de História da África e de Estudos da Diáspora Africana. Ano VI, no XI, Agosto 2013, pp. 28-29.

Acessado em: http://sites.google.com/site/revistasankofa/ em 30/04/2014.

64 Sobre escravos e senhores, e não mais negros contra escravos de senhores, cf. Idem. Op. Cit., 2009, pp. 271-279.

65 Um estudo sobre as diversas finalidades de feitiços e mandigas, conferir a já obra clássica de MELLO E SOUZA. Op. Cit., 2009. Assim também como o artigo excelente de MOTT. "Cotidiano e vivência religiosa: entre a capela e o calundu”. In: MELLO E SOUZA. (org.). 1997, pp. 192-200.

66 HESPANHA, Antonio Manuel. XAVIER, Ângela Barreto. “As redes clientelares”. In: HESPANHA, António Manuel (coord.). História de Portugal, o antigo regime (vol. IV). Dir. José Mattoso. Lisboa: editorial estampa, 1992.

67 ANTT. Tribunal do Santo Ofício. Inquisição de Lisboa. Processos. Documentação dispersa. Denúncias ao tribunal 
um Comissário do Santo Ofício de Olinda, que aglutinou várias denúncias para enviar ao Tribunal da Inquisição ${ }^{68}$. Quem a denunciou foi exatamente outra mulher, de nome Plácida da Fana[?]. A crioula Mariana é colocada dentro do Rol de denunciados como "Feiticeiros do Quibando", o que indicaria que a mesma fosse uma sacerdotisa religiosa com experiências em sortilégios, mesmo que a priori não se saiba ainda quais fossem e como se aplicavam, mas que o Padre encarregado da denúncia já tinha uma bagagem teórica de conhecimento para encarar aquela africana como uma feiticeira ${ }^{69}$.

De situação concreta, o que se pode apreender aqui com um pouco de segurança é o relacionamento entre as mulheres. Não foi citado algum homem na denúncia. As motivações das orações serão ainda uma incógnita, mas o circuito social é empírico, e se pode imaginar possíveis relacionamentos de uma Crioula forra com mulheres brancas (já que uma é "Dona"). Tal relacionamento ajuda a pensar a dinâmica do mundo escravista, e em especial na Vila das Alagoas. Localidade que não havia nenhum tipo de recolhimento feminino, fazendo com que as mulheres se tornassem mais próximas (mas não "mais amigas") de suas criadas e escravas. O intercâmbio cultural muitas vezes extrapolava o que era ditado pela norma católica e pelos agentes Inquisitoriais. Se valendo desse circuito empírico feminino, imagina-se aqui que tais "orações supersticiosas" fossem de cunho afetivo e/ou sexual, comuns e repreendidos no mundo americano ${ }^{70}$. Sua importância para esse texto foi o que bem relatou Laura de Mello e Souza: o uso indiscriminado de santos católicos e até mesmo entidades demoníacas para fazer valer seus efeitos, tudo que a Igreja lutava contra ${ }^{71}$. Mesmo que esse não fosse o objetivo da Crioula Mariana, o Comissário do Santo Ofício encarregado das denúncias já tinha uma bagagem teórica para classificar e perseguir tais atitudes, podendo até mesmo ligá-las mais às pessoas de baixa condição

do santo ofício, por via do padre de olinda e comissário do santo oficio. Acessado em http://digitarq.dgarq.gov.pt/viewer?id=2313753.

68 Na foto número 05 há o seguinte escrito no fólio digitalizado: "Denunciações que se fazem ao Tribunal do Santo Ofício por via do Padre Reitor do Colégio de Olinda Comissário do Santo Ofício”. Cf. Idem, ibidem. Sobre os feiticeiros quibandos e suas atividades na América portuguesa, conferir MOTT, Luiz. "Feiticeiros de Angola na América portuguesa”. Revista Pós Ciências Sociais. v. 5. n. 9/10 jan/dez, São Luis/MA, 2008.

69 De acordo com Luiz Mott. Op. Cit., p. 23: “apontados pelos documentos como um dos sacerdotes mais respeitados e poderosos dentro da hierarquia cerimonial nativa".

70 MELlO E SOUZA. Op. Cit., 2009, pp. 301-303, 306-315. VAINFAS. Op. Cit., 1997. Idem. Op. Cit., 2010. MOTT. Op. Cit., 1997.

71 MELLO E SOUZA. Op. Cit., 2009, p. 306. 
do que às brancas da outra parcela da sociedade.

A título de ilustração, uma das normas do Convento da Ordem Terceira do Carmo na Vila das Alagoas (estritamente para brancos) era justamente impedir que negras e mulatas acompanhassem as noviças brancas em suas atividades, o que indicaria dependência das senhoras com suas criadas no decorrer do dia-a-dia ${ }^{72}$. Não se pode esquecer que os Carmelitas eram defensores da escravidão negra, assim como os Jesuítas, a partir dos sermões de seu mais famoso padre, Antônio Vieira ${ }^{73}$.

\section{3. Pardo desacatando o Sacramento}

Antonio da Silva Maciel era pardo, morador na freguesia do Rosário da Vila do Penedo. Foi acusado por desacato ao sacramento ${ }^{74}$. Ao que tudo indica, em uma Mesa de Comunhão que aconteceu no Convento dos Franciscanos da Vila do Penedo, o pardo Antonio, ao invés de ingerir a "sagrada forma", tirou-a da boca e a guardou em uma Algibeira, causando escândalo depois de descoberto e sendo imediatamente preso e enviado para Olinda. Quatro testemunhas foram chamadas: dois clérigos Franciscanos, o Sargento Mor André de Lemos Ribeiro ${ }^{75}$ e o Alferes dos Pardos Antonio José dos Santos, que também era Oficial de Alfaiate. Curiosamente, foi esse último quem percebeu a ação do pardo Antonio da Silva Maciel e tratou de denunciá-lo. Durante o depoimento em Olinda, o acusado negava todas as acusações, alegando conhecer todas as testemunhas. Entretanto, dizia que o Alferes dos pardos não era um homem "verdadeiro". Ainda sobre o Alferes, é interessante observar a posição do Comissário do Santo Ofício de Olinda,

72 “Proibimos, que na Capela da Ordem não seja admitida nem dado ingresso a nenhuma mulher, que não for $3^{\mathrm{a}}$ Estas por razões a nos notas[?] entrarão sós sem Companhia de mulata ou negra que assim lho mandamos a todos, e a cada uma em vertente da Sua[?] obediência (...)". Instituto Histórico e Geográfico Alagoano. Secção de Documentos. 00031-01-03-11, Ordem 3 $3^{\text {a }}$ de Nossa Senhora do Monte do Carmo. Livro de atas. Vila da Alagoas do Sul, 05 Dez, 1728, fl. 32.

73 VAINFAS, Ronaldo. SANTOS, Georgina Silva dos. "Igreja, Inquisição e religiosidades coloniais”. In: FRAGOSO, João \& GOUVÊA, Maria de Fátima. (orgs.). O Brasil colonial: volume 1 (ca. 1443- ca.1580). - Rio de Janeiro: Civilização Brasileira, 2014, p. 492.

74 ANTT. Tribunal do Santo Ofício. Inquisição de Lisboa. Processos. Processo de António da Silva Maciel. Acessado em http://digitarq.dgarq.gov.pt/details?id=2302967

75 Homem que vive de seus negócios, português, tido recebido provisão de Familiar em 1773. Cf. ROLIM. Op. Cit., 2013, p. 350. 
encarregado do processo: para ele o Alferes pardo é sempre tratado como "preto".

Outra diligência para apurar tal "crime" foi feita em 1778. Ali se destaca como testemunha José Ferreiras, preto das Costas da Mina, cativo da viúva Anna Ritas, moradora na Vila de Penedo, com idade (o escravo) de 23 anos. Confirmava que o pardo sentenciado estava na Igreja no momento, mas que não tinha visto seu "crime" de guardar a "sagrada partícula" da Comunhão, e que quem fez isto foi o Alferes pardo que o acusou. Seu depoimento foi usado (ou intimado) pelo Santo Ofício para desmentir as afirmações de Antonio da Silva Maciel, que dizia não ter ido naquela missa naquele dia. Contudo, não conseguiu provar que a hóstia não tinha sido consagrada, pois tal acusação tinha partido apenas do Alferes dos Pardos.

Novamente, perseguição e classificação ajudam a entender esse papel do Santo Ofício em terras americanas: de um lado um pardo que cometia desacatos (não se descobriram o motivo) aos rituais católicos, de outro um pardo que não é tratado como pessoa verdadeira e até mesmo como preto. Nesse interim os dois pardos entram em choque e um tenta invalidar o depoimento do outro. Em Olinda um homem branco agente do Santo Ofício tratava de enxergar ambos como pessoas sem qualidades sociais e, consequentemente, de depoimentos pouco fidedignos: um criminoso e um preto. Até mesmo a entrada de outro preto escravo mudou um pouco o rumo do jogo, e foram desmentidas algumas atitudes, mas não comprovadas outras, fazendo com que o pardo Antonio Maciel não fosse denunciado por completo. Uma nova Comissão foi passada em 1790, ao que tudo indica, sem ter tido sucesso.

\section{Interpretações finais}

Acerca dos Familiares e Comissários do Santo Ofício, é interessante pensar em uma proteção intragrupo, onde um familiar teria como característica uma espécie de "apoio" dentro de sua classe (militares, mercadores, etc) e seu grupo (família, amizades, etc), tanto de pessoas a favor do habilitado, como do próprio em defesa e auxílio de seus companheiros de ofício ${ }^{76}$. Além disso, o enobrecimento dentro do "grupo" aumentaria a distinção social que os outros viam nele, alargando o respeito do agente do Santo Ofício em suas atividades. Seria, portanto, uma condecoração que era

76 No caso do pardo Antonio Maciel, o aparecimento de André de Lemos Ribeiro (familiar do Santo Ofício), ajuda a entender como havia sim, mesmo com distâncias espaciais, comunicação com os agentes da Inquisição, pois o Comissário do Santo Ofício “alagoano” responsável pela troca de informações era Agostinho Rabelo de Almeida. 
reconhecida por todas as micro-esferas de poder da sociedade, recaindo sobre as classes e grupos ${ }^{77}$. Logo, como disse Pierre Bourdieu, um poder simbólico, silencioso, não sendo necessário o poder arbitrário para ser reconhecido (não mais), visto que sua autoridade seria exatamente pela arbitrariedade que o poder teria escondido por debaixo de seu símbolo ${ }^{78}$. Um agente da inquisição não precisava prender ou julgar ninguém para demonstrar o poder, pois todos já sabiam que seu poder advinha das prerrogativas de exercer mando e punições. Mesmo que suas atribuições não deixassem o agente do Santo Ofício agir de maneira punitiva, os desvios dos próprios familiares, se utilizando do hábito e de seu poder, emitia na mentalidade coletiva popular local o senso comum de que o oficial do Santo Ofício de cadeia mais baixa tinha poderes inquisitoriais ${ }^{79}$. Nesse caso, proteção intragrupo passava pelo campo das etnias africanas e ameríndias, onde a limpeza de sangue era um fator sine qua non para manter e tentar enrijecer os estigmas atribuídos às populações africanas na América e seus descendentes, visando assim garantir sua dominação pelo medo e pela ação.

Homogeneizar negros, pardos e mulatos por conta de atribuições como "baixa condição" é enganoso. Utilizam-se aqui concepções de Edward Thompson. Pensa-se que a união em prol de objetivos comuns contra algum outro grupo é uma das características essenciais em um estudo que utiliza do materialismo histórico para entender a luta de classes, conflitos de grupo, revoltas populares, etc., todas bem observadas dentro de seus contextos histórico-culturais e amarradas com pesquisas empíricas e observações atentas do que seria aquele mundo no recorte espacial e temporal observado $^{80}$. Mesmo ao estudar uma instituição como a Inquisição de Portugal e sua variada gama de perseguição e classificação, que foi de fidalgos à comerciantes, padres à escravos, donzelas à

77 Essa ideia da "proteção intragrupo" partiu de Antonio Filipe Pereira Caetano, em discussões sobre a análise feita sobre esse artigo. Apesar de seu pontapé inicial sobre essa questão do enobrecimento dentro do grupo como estratégia de manutenção de status e proteção, as conclusões esboçadas e retocadas nesse parágrafo se devem ao meu juízo sobre o assunto e a discussão mais ampla, envolvendo interesses de grupo, classes, e micro-esferas de poder.

78 BOURDIEU, Pierre. "Sobre o poder simbólico". In: BOURDIEU, Pierre. O poder simbólico. - 16ª ed. - Rio de Janeiro: Bertrand Brasil, 2012, pp. 1-2, 14-15.

79 Importantíssimo, para esse argumento, é a dissertação de RODRIGUES, Aldair. Sociedade e Inquisição em Minas Colonial: Os Familiares do Santo Ofício (1711-1808). Dissertação (mestrado). FFLCH-USP, departamento de História, São Paulo, 2007. Especialmente o capítulo 2: "Familiares do Santo Ofício e Ação Inquisitorial em Minas", pp. 63-90. E, inserido nesse capítulo, o tópico 2.2: "Prestígio e Poder Inquisitorial: Usos e Abusos do Título de Familiar", pp. 73-84.

80 THOMPSON, Edward P. A formação da classe operária. Rio de Janeiro: Paz e Terra, 1987, pp. 11-12. 
$\operatorname{prostitutas}^{81}$, não se perde de vista que, estudar uma sociedade, e suas diversas atitudes, se torna um todo caótico se o pesquisador não tiver consciência de que a mesma é dividida em "classes" ${ }^{82}$. Não em um sentido rígido como "Senhor de Engenho x Escravo", mas em um âmbito mais teórico (mas não a-empírico) de classes dominantes e classes subalternas ${ }^{83}$ (sempre no plural).

Tomando como base essas assertivas, observaram-se aqui diferentes momentos históricos em que negros, pardos e mulatos foram classificados e perseguidos pelos agentes Inquisitoriais, ou pela camada da sociedade que se valia de suas prerrogativas jurídicas para impor qualquer tipo de tratamento àqueles que estavam sujeitos ao serviço da escravidão, tinham passado por ele ou eram seus descendentes. Do mesmo modo, encontrar exemplos onde esses mesmos personagens sociais se valiam das ações inquisitoriais significaria, não um ato passivo ou de manutenção e perpetuação do sistema, mas de estratégia de resistência contra aqueles que os oprimiam, virando "a arma contra o outro" a partir das rachaduras sociais dos Trópicos. Neste caso, o prisma de análise atentou para atitudes de classe visando resistências contra o regime vigente e os grupos dominantes. Sendo um trabalho de fontes qualitativas e pouco quantitativas, seus contextos locais e temporais ajudam a compreender a pluralidade de situações e, inclusive, a possibilidade do historiador de não se abster da variedade de olhares e análises. Se os conceitos como pactos e negociações estão em voga por conta de estudos empíricos aprofundados e cada vez mais rigorosos, as observações de resistências mediante ação violenta e transgressora não se tornariam menos válidas. Como já explicitado nessa conclusão, apenas com a inserção desses casos em seus contextos, observando seus discursos, é que se poderia perceber ações mais ativas, ou até mesmo de manutenção daquela dominação vigente.

No que tange o âmbito do Santo Ofício, crê-se - e desejo tornar isso uma ideia mais apurada -

81 PIERONI, Geraldo. Vadios e ciganos, heréticos e bruxas: os degredados no Brasil-colônia. - $3^{\text {a }}$ ed. - Rio de Janeiro; Bertrand Brasil: 2006.

82 MARX, Karl. Contribuição à crítica da economia política. / [Tradução a partir da edição francesa] Maria Helena Barreiro Alves; revisão de tradução Carlos Roberto F. Nogueira. - $3^{\mathrm{a}}$ ed. - São Paulo: Martins Fontes, 2003 , pp. 246-258, em especial parágrafo na página 247.

83 Aqui tomo a ideia de Carlo Ginzburg pelo uso do conceito de "classe subalterna", ao invés de classe dominada. Cf. GINZBURG. Op. Cit., 2002, p. 212. "Uso a expressão gramsciana de classes subalternas por ser suficientemente ampla e despida das conotações paternalistas de que está imbuída classes inferiores". (itálicos do autor). Para o conceito de classe, método de estudo e análises sobre dinâmicas de classes subalternas, cf. GRAMSCI, Antonio. “Às margens da História. (História dos grupos sociais subalternos)”. In: GRAMSCI, Antonio. Cadernos do cárcere. Volume 5. Edição e tradução de Luiz Sérgio Henriques; co-edição, Carlos Nelson Coutinho e Marco Aurélio Nogueira. - Rio de Janeiro: Civilização Brasileira, 2002, pp. 129-145. 
que o termo "Alagoas Colonial" também pode ser utilizado quando se trata do estudo da Inquisição. Primeiro, o Regimento dos Ouvidores da Comarca das Alagoas era copiado do Regimento dos Ouvidores da Capitania de Pernambuco. Entre suas atribuições, uma é de interesse aqui: Todo Ouvidor deveria ser Juiz do Fisco Real e dos Confiscados pelo Santo Ofício, e Conservador dos Familiares do Santo Ofício ${ }^{84}$. Nas Ordenações Filipinas, o Rei D. Filipe dava total apoio de sua justiça secular às ações que tocavam "o Santo Ofício da Inquisição" ${ }^{85}$. Todos os oficiais de justiça ajudassem a prender, executar ordens e auxiliar os oficiais do Tribunal na perseguição dos acusados e julgados do crime de heresia. Sobre certa "hospitalidade", o título VI do livro II ordenava que os oficiais de justiça recebessem em suas jurisdições "benignamente" os oficiais da inquisição (Inquisidor Mor, Inquisidores e Oficiais), "E os tenham sob nossa custódia e encomenda, e lhes deem todo favor e ajuda, para seguramente executarem seus ofícios" ${ }^{\prime 86}$. Segundo, discordando em parte com o que afirmou Luiz Mott em um texto sobre a Inquisição em Alagoas ${ }^{87}$, uma vez que os agentes da Inquisição participavam ativamente em denúncias, como testemunhas, em inquirições, habilitações, atividades extra-ofícios e etc., mantiveram inclusive, em alguns casos, troca de informações entre si, como aconteceu entre André de Lemos Ribeiro (Familiar em Penedo) e Agostinho Rabelo de Almeida (Comissário na Vila das Alagoas).

Todavia, os prisioneiros do Santo Ofício eram enviados para Olinda, Bispado da Capitania. Contava-se ainda com situações em que algumas diligências para habilitações do Santo Ofício foram feitas nos espaços pernambucanos e com religiosos do centro de Pernambuco. Mesmo sendo Comarca e com Ouvidor próprio, “Alagoas” não era independente nem completamente desgarrada

84 Informação Geral da Capitania de Pernambuco. In: Anais da Biblioteca Nacional do Rio de Janeiro. Rio de Janeiro: Biblioteca Nacional, Volume XXVIII, 1906, p. 459.

85 Nos seus estudos sobre os bígamos, Luiz Mott afirmou que "no caso de Alagoas, patenteia-se a participação da justiça civil na captura e prisão dos bígamos, demonstrando íntima colaboração entre a cruz e a espada”. Cf. MOTT, Luiz. "Bígamos de Alagoas nas garras da Inquisição". Revista Ultramares. Maceió: Alagoas, GEAC, No 1, Vol. 1, Janeiro-Julho 2012, pp. 40.

86 Segundo Livro das Ordenações Filipinas. Título VI: "Como se cumprirão os mandados dos Inquisidores". In: Ordenações Filipinas. Livros II e II. Lisboa: Fundação Calouste Gulbenkian, 1985, p. 426.

87 “Chama atenção o absoluto silêncio dos oficiais da Inquisição de Alagoas, pois já existindo Comissário do Santo Ofício na comarca desde 1678 e uma dezena de Familiares desde 1696, nenhum destes se envolveu nestes processos de bigamia, cabendo aos Comissários residentes em Recife e Olinda a condução das diligências". Cf. MOTT, Luiz. Op. Cit., 2012, pp. 40-41. Atenta-se aqui que Luiz Mott fala de perseguição contra bígamos, assuntos não tratados nesse corrente texto. 
da administração de Pernambuco. Contudo, isso não faz cair por terra a hipótese de enquadrar as relações inquisitoriais em um âmbito da "Alagoas Colonial”. Os agentes da Inquisição sabiam atuar com autonomia em locais da Comarca das Alagoas, apesar de que em ultima instância devessem prestar esclarecimentos ao Bispado, mas este último não deve ser pensado como ponto inicial da ação Inquisitorial em terras "alagoanas", e sim como ponto final.

Nesse caso, viram-se em Porto Calvo situações onde a maioria das testemunhas faziam questão de se dizer "tidos e havidos como brancos e cristão-velho", enquanto que os pardos apenas um se denominou "livre". No mesmo âmbito, o mundo açucareiro com um número expressivo de latifúndios e formações familiares com o centro de Pernambuco pode ajudar a pensar sobre a denúncia de um homem branco contra o Senhor de Engenho que tentava se habilitar à Familiar do Santo Ofício, indicando algum grau de parentesco com pessoas pardas. Apesar de ser cedo para se afirmar tal assertiva, Porto Calvo aqui se vê como um espaço onde haveria mais divisões latentes entre brancos, negros e os miscigenados por conta de sua estrutura rural mais ligada ao mundo do açúcar $^{88}$.

Para Vila das Alagoas, têm-se um espaço "híbrido", pois a estrutura do açúcar era forte naquele espaço, assim como a cultura do tabaco e também da pecuária, principalmente com as constantes destruições dos Mocambos na região de Palmares ${ }^{89}$. A miscigenação e os conflitos aconteceriam, visto o contato com espaços negros e também ameríndios, como por exemplo, a aldeia de Santo Amaro, que ficou décadas enraizada nos espaços da Vila das Alagoas ${ }^{90}$. Uma maior dinâmica poderia ser incorporada por conta de seu pólo lagunar, que garantia um intercâmbio comercial (e de gentes) maior que outras Vilas em alguns momentos ${ }^{91}$.

Sobre a Vila de Penedo do Rio de São Francisco, vê-se um espaço da pecuária muito forte,

88 CAETANO, Antonio F. P. "Nos confins, nas vilas e na Comarca... A construção da autonomia política, administrativa e jurisdicional Alagoana (Século XVI-XVIII)”. In: CAETANO, Antonio Filipe Pereira (org.). Alagoas e o império colonial português: ensaios sobre poder e administração (séculos XVII - XVIII). Maceió: Cepal, 2010, p. 30.

89 ROLIM. Op. Cit., 2012. DIÉGUES Jr. Manuel. O banguê nas alagoas: traços da influência do sistema econômico do engenho de açúcar na vida e na cultura regional. - $3^{\mathrm{a}}$ ed.; prefácio de Gilberto Freyre; capas e vinhetas de Santa Rosa. - Maceió, EDUFAL, 2006.

90 AHU. Alagoas Avulsos. Documento 38.

91 CAETANO. Op.cit., 2010, p. 30-31. A expressão “pólo lagunar” é de A. Caetano. 
mesmo tendo latifúndios açucareiros com alguns engenhos ${ }^{92}$. A incidência de pardos era expressiva (mas não se arrisca ser maior do que outros lugares) e ganhava força e estabilidade por conta do que se convencionou chamar "Civilização do Couro", que ajudava os mestiços a terem uma mobilidade maior dentro da sociedade, mesmo com os variados tipos de ataques de cunho desclassificatório ${ }^{93}$. Seria nessa Vila que se institucionalizaram uma confraria para homens pardos, sendo ela a Irmandade de São Gonçalo Garcia dos Homens Pardos, que tinha em seus quadros internos homens brancos e um se tornou Comissário do Santo Ofício ${ }^{94}$.

O estudo sobre Classes e Grupos ainda não deve receber um ponto final, visto as diferentes concepções teóricas e ideológicas que são imbuídas nos dois conceitos que atravessaram as diferentes correntes das ciências sociais e historiográficas. São palavras que receberam significados diferentes e práticos no momento de uso e durante a escrita da história, para designá-las no passado visando uma justificativa no presente. Jacques Le Goff, sobre as três ordens do feudalismo, utiliza o termo classe e justifica sua posição metodológica do termo:

“Este vocabulário é ideológico, normativo, mesmo que, para ser eficaz, ele demonstre certa concordância com as 'realidades' sociais. O termo ordo, que

92 Idem. Op. Cit., 2010, pp. 30.

93 Deixa-se aqui em aberto, ainda, os debates sobre a relativa "liberdade" que os habitantes tinham nos sertões, muitas vezes encarados como atividades "democráticas" e distantes da escravidão. Caio Prado Júnior, Luiz Felipe de Alencastro e Dirceu Lindoso formulam a ideia das atividades pecuárias como "apartadas do escravismo" (expressão essa de Alencastro). Cf. PRADO JÚNIOR. Op. Cit., pp. 184-208. LINDOSO, Dirceu. A razão quilombola: estudos em torno do conceito quilombola de nação etnográfica. Maceió: EDUFAL, 2011, pp. 33-37. ALENCASTRO, Luiz Felipe de. O trato dos viventes: formação do Brasil no atlântico sul. São Paulo: companhia das letras, 2000, p. 341.

94 Gabriel de Sampaio foi diversas vezes Juiz da Irmandade de São Gonçalo Garcia, atuante como Comissário extraofício pela Inquisição de Lisboa, administrador do Hospital da Irmandade na Vila de Penedo, além de participante também em outras duas Confrarias para brancos na Vila do Penedo, recebeu em 1807 o hábito da Ordem de Cristo, e em 1808 foi contemplado com o Hábito de Comissário do Santo Ofício da Inquisição de Lisboa para atuar na Comarca das Alagoas, pois alegava em seu pedido (em 1807) que o último Comissário tinha falecido um ano antes (1806), sendo ele Agostinho Rabelo de Almeida, na Vila das Alagoas (AHU. Alagoas Avulsos. Documento 438), o que indicaria contatos próximos entre os personagens em torno de uma classe em comum: "porque não só há extrema falta de comissários e notários na Comarca das Alagoas ainda no ano próximo preterito faleceu o único que havia”. Cf. ANTT. Tribunal do Santo Ofício. Habilitações. Gabriel. Maço 4, doc. 40. 
é mais carolíngio do que propriamente feudal, pertence ao vocabulário religioso e aplica-se assim a uma visão religiosa da sociedade - aos clérigos e laicos, ao espiritual e ao temporal. Neste caso só pode haver duas ordens, o clero e o povo (cleros et populus), e os textos dizem na maioria das vezes utraque ordo (uma e outra ordem). Os juristas modernos quiseram estabelecer uma distinção entre a classe, cuja definição seria econômica, e a ordem, cuja definição seria jurídica. Na verdade, a ordem é religiosa mas, tanto quanto a classe, funda-se em bases socioeconômicas. A tendência dos autores e utilizadores do esquema tripartido da Idade Média de fazer das três 'classes' nele compreendidas 'ordens' respondia à intenção de sacralizar esta estrutura social, fazendo dela uma realidade objetiva e eterna criada e desejada por Deus, tornando impossível uma revolução social” 95 .

Portanto, deve haver um porquê da escolha de tal conceito, mesmo sendo Estado/Ordem o "correto" e utilizado na época ${ }^{96}$, a sua difusão e propagação visava uma posição ideológica de harmonia. Ordem dá a impressão de ausência de conflitos, enquanto que Classes exprimiam os antagonismos sociais e as lutas travadas entre e dentro desses Estados, em todas as esferas de poder - cultural (simbólico), econômico (práticas mercantis), político (poder de mando), jurídico (utilização dos privilégios), religioso (ordenamento e repressão social). Ainda que os mesmos não se apresentassem como uma Classe revolucionária. Apesar desse texto ainda deixar o assunto em suspenso, esquivar-se de seu debate, nem que seja no âmbito - ainda - teórico ${ }^{97}$, é uma tarefa que atualmente os diferentes estudos sobre os diferentes segmentos sociais não deve praticar, sendo necessário observar, em vários acontecimentos sociais, inclusive movimentos mais estruturados, as características de descontentamento entre Estados e, em um caráter mais direcionado e abstrato, da ordem que era imposta e tratada como sinônimo de harmonia. Essa opção ideológica e metodológica é reforçada (no âmbito do debate) quando se têm um espaço como a América portuguesa. Aqui, mesmo com todo tipo de pacto, negociação e interesses reivindicatórios que

95 LE GOFF, Jacques. A civilização do ocidente medieval. - Bauro, SP: Edusc, 2005, p. 262.

96 HESPANHA, António Manuel. As vésperas do Leviathan. Instituições e poder político: Portugal - séc. XVII. Lisboa: Almedina, 1994, pp. 307-324. GODINHO, Vitorino Magalhães. Estrutura da antiga sociedade portuguesa. $4^{\mathrm{a}}$ ed. Lisboa: arcádia, 1980, pp. 71-116.

97 Mesmo com avaliações empíricas em cima de documentos político-administrativos e inquisitoriais. 
muitas vezes não eram revolucionários, havia a repressão e as diferenças de interesses, seja no universo social dos homens brancos, dos indígenas ou dos africanos.

\section{Documentos manuscritos:}

Arquivo Nacional Torre do Tombo.

Tribunal do Santo Ofício:

Conselho Geral. Habilitações. José. Maço 103 - doc. 1465; Gabriel. Maço 4, doc. 40

Habilitações incompletas. Maço 17, doc. 677.

Inquisição de Lisboa:

Caderno do Promotor. Livro 324, fls. 115-115v. Retirados de http://digitarq.dgarq.gov.pt/.

Processos. Documentação dispersa. Denúncias ao tribunal do santo ofício, por via do padre de olinda e comissário do santo oficio. Acessado em http://digitarq.dgarq.gov.pt/viewer? $\underline{\mathrm{id}=2313753}$.

Processos. Processo de António da Silva Maciel. Acessado em http://digitarq.dgarq.gov.pt/details? id=2302967

Arquivo Histórico Ultramarino.

Alagoas Avulsos. Documento 38; 164; 438

Instituto Histórico e Geográfico Alagoano:

Secção de Documentos. 00031-01-03-11, Ordem 3 ${ }^{\mathrm{a}}$ de Nossa Senhora do Monte do Carmo. Livro de atas. Vila da Alagoas do Sul, 05 Dez, 1728.

\section{Documentação impressa:}

ANTONIL, André João. Cultura e opulência no Brasil. Texto confrontado com o da edição de 1711; com um estudo biobibliográfico por Affonso de E. Taunay. $3^{\mathrm{a}}$ ed. Belo Horizonte: Ed. Itatiaia; São Paulo. Ed. da Universidade de São Paulo, 1982.

BLUTEAU, Raphael. Vocabulario portuguez \& latino. Áulico, anatômico, architectonico... Coimbra: Collegio das Artes da Companhia de Jesus, 1712-1728, Acessado em www.brasiliana.usp.br/dicionario/edicao/1 em 16/01/2014 às 17:58 
Informação Geral da Capitania de Pernambuco. In: Anais da Biblioteca Nacional do Rio de Janeiro. Rio de Janeiro: Biblioteca Nacional, Volume XXVIII, 1906.

Ordenações Filipinas. Livros II e II. Lisboa: Fundação Calouste Gulbenkian, 1985.

VIDE, Sebastião Monteiro da. Constituições Primeiras do Arcebispado da Bahia. Estudo introdutório e edição Bruno Feitler, Evergton Sales Souza; Istvan Jancsó, Pedro Puntoni (organizadores). - São Paulo: Editora da Universidade de São Paulo, 2010.

Referências Bibliográficas: livros, artigos, dissertações.

BETHENCOURT, Francisco. História das Inquisições: Portugal, Espanha, Itália. Lisboa: Círculo de leitores, 1994.

BOSCHI, Caio. "Estruturas eclesiásticas e Inquisição". In: BETHENCOURT, Francisco. CHAUDHURI, Kirti. (dir.) História da Expansão Portuguesa vol. II: Do Índico ao Atlântico (1570-1697). Lisboa: círculo dos leitores, 1998.

BOURDIEU, Pierre. "Sobre o poder simbólico". In: BOURDIEU, Pierre. O poder simbólico. - $16^{\mathrm{a}}$ ed. - Rio de Janeiro: Bertrand Brasil, 2012.

BOXER, Charles. O império marítimo Português. 1415-1825. Tradução de Anna Olga de Barros Barreto. São Paulo: Companhia das Letras, 2002.

BRAGA, Isabel M. R. Mendes Drumond. "A mulatice como Impedimento de acesso ao 'Estado do Meio"”. In: Actas do Congresso Internacional Espaço Atlântico de Antigo Regime: poderes e sociedades. Lisboa, 2 a 5 de Novembro de 2005. Texto acessado em 09/05/2014. Em:

http://cvc.instituto-camoes.pt/eaar/coloquio/comunicacoes/isabel drumond braga.pdf

BURKE, Peter. Variedades de história cultural. - Rio de Janeiro: Civilização Brasileira, 2000.

. "Nos confins, nas vilas e na Comarca... A construção da autonomia política, administrativa e jurisdicional Alagoana (Século XVI-XVIII)”. In: CAETANO, Antonio Filipe Pereira (org.). Alagoas e o império colonial português: ensaios sobre poder e administração (séculos XVII XVIII). Maceió: Cepal, 2010, p. 30.

CALAINHO, Daniela Buono. Agentes da fé: familiares da Inquisição portuguesa no Brasil colonial. Bauru: EDUSC, 2006.

FARIA, Sheila de Castro. A colônia brasileira: economia e diversidade. - São Paulo: Moderna, 1997. 
FLANDRIN, Jean-Louis. "Familia”. In: Le GOFF, Jacques. CHARTIER, Roger. REVEL, Jacques. (dir.) A Nova História. Coimbra: Almedina, 1990, p. 213.

GODINHO, Vitorino Magalhães. Estrutura da antiga sociedade portuguesa. $4^{\mathrm{a}}$ ed. Lisboa: arcádia, 1980, pp. 71-116.

GRAMSCI, Antonio. "Às margens da História. (História dos grupos sociais subalternos)”. In: GRAMSCI, Antonio. Cadernos do cárcere. Volume 5. Edição e tradução de Luiz Sérgio Henriques; co-edição, Carlos Nelson Coutinho e Marco Aurélio Nogueira. - Rio de Janeiro: Civilização Brasileira, 2002, pp. 129-145.

HESPANHA, António Manuel. "Para uma teoria da história institucional do Antigo Regime". In: HESPANHA, António Manuel (org.). Poder e Instituições na Europa de Antigo Regime. Lisboa: Fundação Calouste Gulbenkian, 1984, p. 11.

XAVIER, Ângela Barreto. "As redes clientelares". In: HESPANHA, António Manuel (coord.). História de Portugal, o antigo regime (vol. IV). Dir. José Mattoso. Lisboa: editorial estampa, 1992.

LARA, Silvia Hunold. "Conectando historiografias: a escravidão africana e o Antigo Regime na América portuguesa". In: BICALHO, Maria Fernanda Baptista. FERLINI, Vera Lúcia Amaral. (orgs.). Modos de governar: idéias e práticas políticas no império português - séculos XVIXIX. - São Paulo: Alameda, 2005.

LE GOFF, Jacques. A civilização do ocidente medieval. - Bauro, SP: Edusc, 2005.

MATTOS, Hebe. "Colonização e escravidão no Brasil - Memória e historiografia". In: F FRAGOSO, João \& GOUVÊA, Maria de Fátima. (orgs.). O Brasil colonial: volume 1 (ca. 1443ca.1580). - Rio de Janeiro: Civilização Brasileira, 2014.

MARQUES, Dimas. "Por meus méritos às minhas mercês". Elites administrativas e a distribuição de cargos (Comarca das Alagoas - século XVII-XVIII). Universidade Federal de Alagoas, Instituto de Ciências Humanas, Comunicação e Artes, Departamento de História, Monografia: Maceió, 2011.

MARX, Karl. Contribuição à crítica da economia política. / [Tradução a partir da edição francesa] Maria Helena Barreiro Alves; revisão de tradução Carlos Roberto F. Nogueira. - $3^{\mathrm{a}}$ ed. - São Paulo: Martins Fontes, 2003.

ENGELS, Friedrich. A ideologia alemã. Organização, tradução, prefácio e notas de Marcelo Backes. - Rio de Janeiro: Civilização Brasileira, 2007, p. 71.

MOTT, Luiz. “A inquisição em Alagoas”. Debates de História Regional (Revista do departamento de história da UFAL), $\mathrm{n}^{\mathrm{o}}$ 1, Maceió, 1992.

"Cotidiano e vivência religiosa: entre a capela e o calundu". In: MELLO E SOUZA, Laura de (org.). História da vida privada no brasil: Cotidiano e vida privada na América portuguesa, vol. I. NOVAIS, Fernando. (dir.). - São Paulo: Companhia das Letras, 1997.

. "Feiticeiros de Angola na América portuguesa". Revista Pós Ciências Sociais. v. 5. n. 9/10 jan/dez, São Luis/MA, 2008. 
. "Bígamos de Alagoas nas garras da Inquisição". Revista Ultramares. Maceió: Alagoas, GEAC, No 1, Vol. 1, Janeiro-Julho 2012.

NOVINSKY, Anita. Entrevista por Rodrigo Elias. Revista de História da Biblioteca Nacional, Ano 7, $n^{\circ}$ 73, Outubro de 2011, p. 32.

PRADO JÚNIOR, Caio. Formação do Brasil contemporâneo: colônia. - $23^{\text {a }}$ ed. São Paulo: Brasiliense, 2008.

RODRIGUES, Aldair. Sociedade e Inquisição em Minas Colonial: Os Familiares do Santo Ofício (1711-1808). Dissertação (mestrado). FFLCH-USP, departamento de História, São Paulo, 2007.

ROLIM, Alex. "Mercadores da inquisição. Notas sobre estratégias de ascensão social (Alagoas Colonial, c. 1674 - c. 1820)". Historien (Petrolina). Ano 4, no 9. Jul/Dez 2013. Acessado em www.revistahistorien.com

SANTOS, Irinéia M. Franco dos. "A Caverna do Diabo: O ensaio romântico de Valeriano De Souza e as religiões afro-brasileiras em Alagoas, no séc. XIX”. Sankofa. Revista de História da África e de Estudos da Diáspora Africana. Ano VI, $\mathrm{n}^{\circ}$ XI, Agosto 2013. Acessado em: http://sites.google.com/site/revistasankofa/ em 30/04/2014.

SCHMIDT, Benito Bisso. "História e Biografia". In: CARDOSO, Ciro Flamarion \& VAINFAS, Ronaldo. (orgs.) Novos domínios da história. - Rio de Janeiro: Elsevier, 2012.

SCHWARTZ, Stuart. Segredos internos: engenhos e escravos na sociedade colonial, 1550-1835. São Paulo: Companhia das Letras, 1988, pp. 225-231

"os escravos: $<<$ remédio de todas as outras cousas $>>$ ". In: BETHENCOURT, Francisco. CHAUDHURI, Kirti. (dir.) História da Expansão Portuguesa vol. II: Do Índico ao Atlântico (1570-1697). Lisboa: círculo dos leitores, 1998.

SILVA, Maria Beatriz Nizza da. Sistema de casamento no Brasil colonial. São Paulo: editoria da Universidade de São Paulo, 1984

SOUZA, Laura de Mello e. O diabo e a terra de Santa Cruz: feitiçaria e religiosidade popular no Brasil colonial. - 2a ed. São Paulo: Companhia das Letras, 2009.

TORRES, José Veiga. "Da Repressão Religiosa para a Promoção Social. A Inquisição como instância legitimadora da promoção social da burguesia mercantil”. Revista Crítica de Ciências Sociais, $n^{\circ}$ 40, Outubro 1994.

VAINFAS, Ronaldo. Trópico dos pecados: moral, Sexualidade e inquisição no Brasil. - Rio de Janeiro: civilização Brasileira, 2010.

"Moralidades brasílicas: deleites sexuais e linguagem erótica na sociedade escravista". In: MELLO E SOUZA, Laura de (org.). História da vida privada no brasil: Cotidiano e vida privada na América portuguesa, vol. I. NOVAIS, Fernando. (dir.). - São Paulo: Companhia das Letras, 1997, pp. 238-239.

SANTOS, Georgina Silva dos. "Igreja, Inquisição e religiosidades coloniais". In: FRAGOSO, João \& GOUVÊA, Maria de Fátima. (orgs.). O Brasil colonial: volume 1 (ca. 1443- 
Sankofa. Revista de História da África e de Estudos da Diáspora Africana Ano VII, NºXIV, Dezembro/2014 ca.1580). - Rio de Janeiro: Civilização Brasileira, 2014. 